\title{
A stable phylogenomic classification of Travunioidea (Arachnida, Opiliones, Laniatores) based on sequence capture of ultraconserved elements
}

\author{
Shahan Derkarabetian ${ }^{1,2,7}$, James Starrett ${ }^{3}$, Nobuo Tsurusaki ${ }^{4}$, \\ Darrell Ubick ${ }^{5}$, Stephanie Castillo ${ }^{6}$, Marshal Hedin'
}

I Department of Biology, San Diego State University, San Diego, California 92182-4614, USA 2 Department of Biology, University of California, Riverside, Riverside, California 92521, USA 3 Department of Biological Sciences, Auburn University, Auburn, Alabama 36849, USA 4 Laboratory of Zoological Systematics, Faculty of Agriculture, in Faculty of Regional Sciences Building, Tottori University, Tottori, 680-8551, Japan 5 Department of Entomology, California Academy of Sciences, San Francisco, California 94118, USA 6 Department of Entomology, University of California, Riverside, Riverside, California 92521, USA 7 Present address: Department of Organismic and Evolutionary Biology, Museum of Comparative Zoology, Harvard University, 26 Oxford Street, Cambridge, MA 02138, USA

Corresponding author: Shahan Derkarabetian (sderkarabetian@gmail.com)

Academic editor: G. Giribet | Received 10 March 2018 | Accepted 26 April 2018 | Published 28 May 2018

http://zoobank.org/OB57270D-C24C-4D4D-A04F-15CA442E0A07

Citation: Derkarabetian S, Starrett J, Tsurusaki N, Ubick D, Castillo S, Hedin M (2018) A stable phylogenomic classification of Travunioidea (Arachnida, Opiliones, Laniatores) based on sequence capture of ultraconserved elements. ZooKeys 760: 1-36. https://doi.org/10.3897/zookeys.760.24937

\begin{abstract}
Molecular phylogenetics has transitioned into the phylogenomic era, with data derived from next-generation sequencing technologies allowing unprecedented phylogenetic resolution in all animal groups, including understudied invertebrate taxa. Within the most diverse harvestmen suborder, Laniatores, most relationships at all taxonomic levels have yet to be explored from a phylogenomics perspective. Travunioidea is an early-diverging lineage of laniatorean harvestmen with a Laurasian distribution, with species distributed in eastern Asia, eastern and western North America, and south-central Europe. This clade has had a challenging taxonomic history, but the current classification consists of -77 species in three families, the Travuniidae, Paranonychidae, and Nippononychidae. Travunioidea classification has traditionally been based on structure of the tarsal claws of the hind legs. However, it is now clear that tarsal claw structure is a poor taxonomic character due to homoplasy at all taxonomic levels. Here, we utilize DNA sequences derived from capture of ultraconserved elements (UCEs) to reconstruct travunioid relation-
\end{abstract}

Copyright Shahan Derkarabetian et al. This is an open access article distributed under the terms of the Creative Commons Attribution License (CC BY 4.0), which permits unrestricted use, distribution, and reproduction in any medium, provided the original author and source are credited. 
ships. Data matrices consisting of 317-677 loci were used in maximum likelihood, Bayesian, and species tree analyses. Resulting phylogenies recover four consistent and highly supported clades; the phylogenetic position and taxonomic status of the enigmatic genus Yuria is less certain. Based on the resulting phylogenies, a revision of Travunioidea is proposed, now consisting of the Travuniidae, Cladonychiidae, Paranonychidae (Nippononychidae is synonymized), and the new family Cryptomastridae Derkarabetian \& Hedin, fam. n., diagnosed here. The phylogenetic utility and diagnostic features of the intestinal complex and male genitalia are discussed in light of phylogenomic results, and the inappropriateness of the tarsal claw in diagnosing higher-level taxa is further corroborated.

\section{Keywords}

cave evolution, harvestmen, historical biogeography, Holarctic, target enrichment, taxonomy

\section{Introduction}

The arachnid order Opiliones is taxonomically rich, comprising 46 families, over 1,640 genera, and more than 6,600 described species (summarized in Kury 2000, Machado et al. 2007, Kury 2013). Within Opiliones, considerable phylogenetic progress has been made over the past -10 years, summarized by Pinto-da-Rocha et al. (2007) and reviewed/updated in Giribet et al. (2010) and Giribet and Sharma (2015). This progress includes transcriptome-based phylogenomic approaches used in Hedin et al. (2012a), Sharma and Giribet (2014) and Fernández et al. (2017). Opiliones diversity falls into four primary clades, including the "mite harvestmen" (Cyphophthalmi), typical "daddy longlegs" (Eupnoi and Dyspnoi), and the "short-legged" or "armored" harvestmen (Laniatores). Laniatores is strongly supported as monophyletic, is the most species-rich group of harvestmen (with more than 4,100 described species) and can be found on all continents except for Antarctica. Many laniatoreans are tropical, where these animals are conspicuous and occupy a wide variety of habitats. Temperate laniatoreans are less noticeable, and in the Holarctic, are mostly small-bodied $(-1.5-4 \mathrm{~mm})$ predators restricted to cryophilic habitats (e.g., under decaying logs or rocks, in leaf litter, in caves, etc.).

The molecular phylogenetic research of Giribet et al. (2010), which focused on relationships within Laniatores, formed the framework for further systematic research in these arachnids. Following this study, Sharma and Giribet (2011) conducted a phylogenetic analysis representing the most inclusive study of Laniatores to date. These authors recovered four primary laniatorean lineages (Fig. 1A), including the Synthetonychiidae Forster, 1954 (New Zealand), Triaenonychidae Sørensen, 1886 (mostly south temperate), Travunioidea Absolon \& Kratochvíl, 1932 (north temperate), and Grassatores Kury, 2002 (broadly distributed, most diversity in the tropics). Although the sampling of travunioid taxa in these studies was incomplete (6-7 of 24 travunioid genera sampled), these molecular phylogenetic results and morphology (reviewed in Giribet and Kury 2007) support the monophyly of a north temperate lineage that constitutes the focal group of this study, the Travunioidea (Figs 1,2).

Classification and generic level diagnoses within the Travunioidea have traditionally been based on structure of the tarsal claws of hind legs III and IV, particularly the 

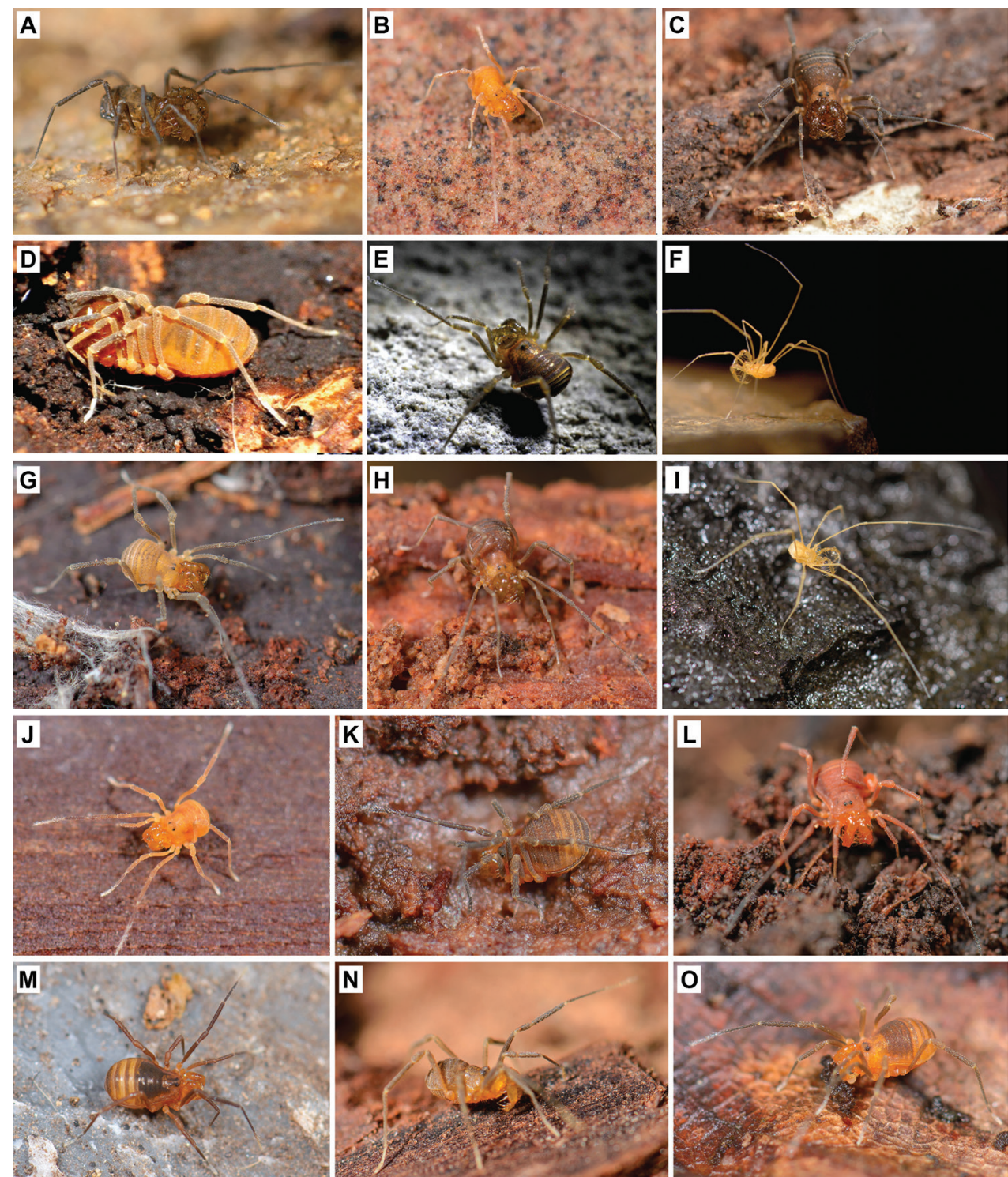

Figure I. Photographs of live travunioid harvestmen. A Theromaster brunneus B Erebomaster sp. C Cryptomaster leviathan $\mathbf{D}$ Holoscotolemon lessiniense $\mathbf{E}$ Peltonychia leprieurii $\mathbf{F}$ Trojanella serbica $\mathbf{G}$ Briggsus sp. H Isolachus spinosus I Speleonychia sengeri J Yuria pulcra K Paranonychus brunneus $\mathbf{L}$ Sclerobunus nondimorphicus $\mathbf{M}$ Metanippononychus sp. N Zuma acuta $\mathbf{O}$ Kainonychus akamai. All photos by MH, except D, E (courtesy of and copyright A. Schönhofer), and $\mathbf{F}$ (courtesy of and copyright I. Karaman).

number of side branches on the median prong. It is now widely-recognized that tarsal claw structure is a poor taxonomic character in this clade, as claw structure is highly homoplastic and variable at all taxonomic levels (e.g., Shear 1977, Maury 1988, Hunt and Hickman 1993, Karaman 2005, Shear and Derkarabetian 2008). For example, 


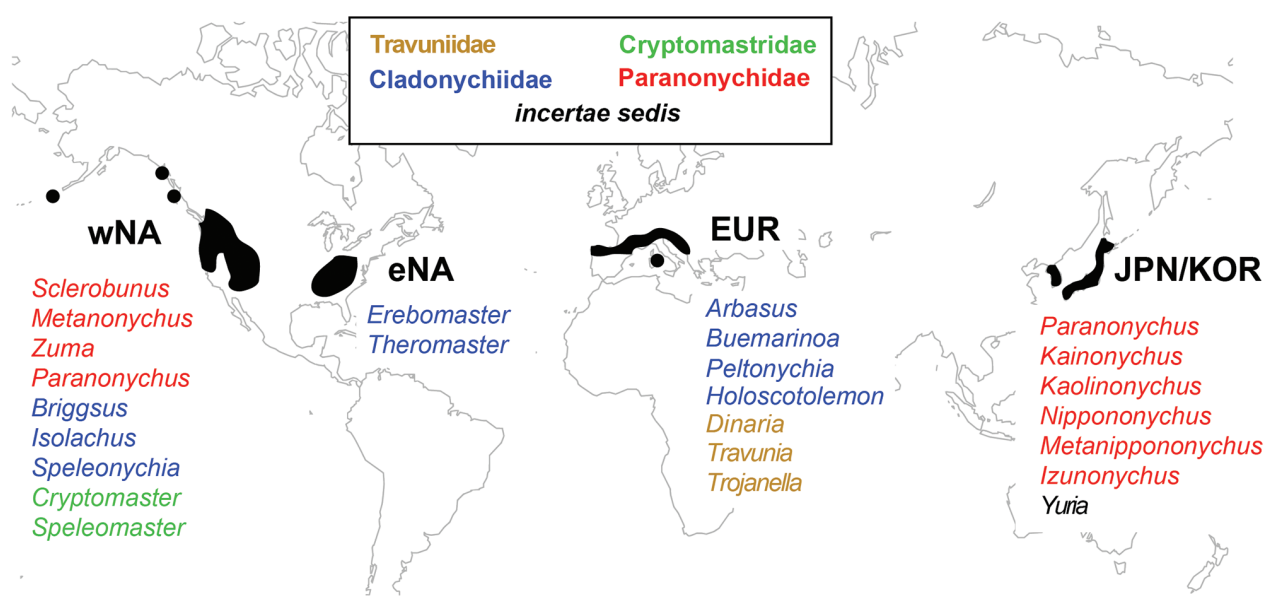

Figure 2. Geographic distribution of travunioid genera. Colors correspond to classification proposed in this study. Abbreviations: wNA = western North America, eNA = eastern North America, EUR = central and southern Europe, JPN/KOR = Japan and South Korea.

many travunioids were formerly grouped with the Triaenonychidae, sharing tridentshaped tarsal claw morphology. The transfer of all "north temperate triaenonychids" to the Travunioidea was first hinted at by Staręga (1971), proposed based on intestinal morphology by Dumitrescu $(1975,1976)$, and has since been supported with additional morphological (Giribet and Kury 2007, Mendes 2009) and molecular phylogenetic data (e.g., Derkarabetian et al. 2010, Giribet et al. 2010, Sharma and Giribet 2011). Other somatic morphological characters have been used to diagnose travunioid taxa (e.g., free lateral sclerites), but these characters may be retained plesiomorphic states (Kury 2007a) and/or potentially neotenic (Rambla 1980, Hunt and Hickman 1993). To illustrate the difficulty in the using these characters specifically in travunioids, Karaman (2005) described the monotypic genus Trojanella Karaman, 2005 yet left it unplaced within Travunioidea due to the uncertainty and homoplasy surrounding the diagnostic characters typically used to assign travunioid taxa.

Travunioidea has had a long and complicated taxonomic history dating back to 1861 with the description of the first species. Many European species were described by multiple authors throughout the late 1800s and early 1900s, resulting in many nomenclatural errors, comprehensively discussed in Kury and Mendes (2007). The vast majority of travunioid diversity was described during the mid-1960s to mid-1970s by Briggs (1969, 1971a, 1971b, 1974) in North America and Suzuki (1964, 1972, 1975a, 1975b, 1976) in Japan. Following this burst of taxonomic research very few studies focused on travunioids with the exception of two describing new European species (Tedeschi and Sciaky 1994, Karaman 2005), until sustained research began in the mid2010s. During the mid-late 2010s, continued morphological work and the incorporation of genetic data confirmed the unsuitability of tarsal-claw taxonomy and resulted in several nomenclatural changes including new familial names (Giribet et al. 2010) and synonymies at the subfamilial, generic, and species levels (Shear and Derkarabet- 
ian 2008, Derkarabetian and Hedin 2014). Recent studies incorporating genetic and morphological analyses have led to the discovery, delimitation, and description of new travunioid species from western North America (Derkarabetian and Hedin 2014, Starrett et al. 2016).

Kury et al. (2014) recently provided a checklist of Travunioidea, made some taxonomic revisions, and provided a new taxonomy which serves as the starting point for this study. In this classification, Travunioidea includes 77 species/subspecies in 24 genera classified into three families, the Travuniidae Absolon \& Kratochvíl, 1932 (including the historical Travuniidae, Cladonychiidae Hadži, 1935, and Briggsidae Özdikmen \& Demir, 2008 as subfamilies), Paranonychidae Briggs, 1971, and Nippononychidae Suzuki, 1975. A summary of the historical classifications is presented in Table 1. While the monophyly of Travunioidea is almost certain, internal phylogenetic relationships remain largely unresolved. The most comprehensive phylogenetic analyses were conducted by Derkarabetian et al. (2010) and included samples from ten genera. Although this study was not focused on relationships among Travunioidea and only included samples from North America, the resulting phylogeny indicated a need for a taxonomic revision as multiple families and subfamilies were recovered as as para- or polyphyletic.

A robust genus-level phylogeny of Travunioidea and a stable classification would provide an important anchor for future taxonomic and evolutionary studies in this group. The stability of any phylogenetics-based classification relies upon high confidence and support for internal relationships. In other animal groups, genomic- or subgenomic-scale approaches have produced phylogenies with generally higher nodal support and have resolved difficult relationships (e.g., Blaimer et al. 2015, Garrison et al. 2016, Hamilton et al. 2016, Baca et al. 2017, Branstetter et al. 2017, Breinholt et al. 2017, Hedin et al. 2018). In this paper we utilize DNA sequences derived from capture of ultraconserved elements (UCEs; Faircloth 2017) to reconstruct phylogenomic relationships within Travunioidea. The phylogenetic utility of UCE data at multiple evolutionary scales has been demonstrated in other arachnid lineages (Starrett et al. 2017, Hedin et al. 2018). Our taxon sample includes 21 of 24 described genera and all currently and historically recognized travunioid families and subfamilies, plus outgroups. Although previous studies have examined relationships among Laniatores using a wider range of taxa (Giribet et al. 2009, Sharma and Giribet 2011), this study includes the most complete taxon set to date for Travunioidea.

\section{Materials and methods}

\section{Taxon sampling}

Fifty-seven specimens were included in this study (Suppl. material 1), including 40 Travunioidea, 14 non-travunioid Laniatores (eight Triaenonychidae, two Synthetonychiidae, and four Grassatores), and single representatives from each of the other three harvestmen suborders. Forty-nine samples were newly sequenced for this study; raw 
Table I. Historical classification of the Travunioidea. Traditional classification refers to the taxonomy in place after the mid-1970s.

\begin{tabular}{|c|c|}
\hline Traditional & Kury et al. (2014) \\
\hline Travunioidea & Travunioidea \\
\hline Travuniidae & Travuniidae \\
\hline Abasola & Travuniinae \\
\hline Arbasus & Arbasus \\
\hline Buemarinoa & Buemarinoa \\
\hline Dinaria & Dinaria \\
\hline Kratochviliola & Peltonychia \\
\hline Peltonychia & Speleonychia \\
\hline Travunia & Travunia \\
\hline Speleonychia & Trojanella \\
\hline Yuria & Cladonychiinae \\
\hline Cladonychiidae & Cryptomaster \\
\hline Cryptomaster & Erebomaster \\
\hline Erebomaster & Holoscotolemon \\
\hline Holoscotolemon & Speleomaster \\
\hline Speleomaster & Theromaster \\
\hline Theromaster & Briggsinae \\
\hline Pentanychidae & Briggsus \\
\hline Pentanychus & Isolachus \\
\hline \multicolumn{2}{|l|}{ Isolachus } \\
\hline Triaenonychoidea (in part) & Paranonychidae \\
\hline “northern" Triaenonychidae & Sclerobuninae \\
\hline Sclerobuninae & Sclerobunus \\
\hline Sclerobunus & Zuma \\
\hline Cyptobunus & Paranonychinae \\
\hline Zuma & Paranonychus \\
\hline Paranonychinae & Metanonychus \\
\hline Paranonychus & Kaolinonychus \\
\hline Metanonychus & Kainonychus \\
\hline Kainonychus & Nippononychidae \\
\hline Kaolinonychinae & Nippononychus \\
\hline Kaolinonychus & Metanippononychus \\
\hline Mutsunonychus & Izunonychus \\
\hline Nippononychinae & Yuria \\
\hline \multicolumn{2}{|l|}{ Nippononychus } \\
\hline \multicolumn{2}{|l|}{ Metanippononychus } \\
\hline Izunonychus & \\
\hline
\end{tabular}

reads for other taxa are from Starrett et al. (2017). We included two samples for most travunioid genera (in most cases from two different species), except for Trojanella and Travunia Absolon, 1920, both of which were represented by a single specimen. We 
were unable to include three European travuniid genera (Arbasus Roewer, 1935, Buemarinoa Roewer, 1956, and Dinaria Roewer, 1935) as these are extremely rare and difficult to obtain cave-dwelling taxa.

\section{Molecular data collection}

Genomic DNA was extracted from whole bodies using the Qiagen DNeasy Blood and Tissue Kit (Qiagen, Valencia, CA). For several larger specimens (body size greater than 3-4 mm) only legs, pedipalps, and chelicerae were used in extractions. Extractions were quantified using a Qubit Fluorometer (Life Technologies, Inc.) Broad Range kit, and quality was assessed via gel electrophoresis on a $0.8 \%$ agarose gel. Up to $500 \mathrm{ng}$ of genomic DNA was used in sonication procedures, using a Bioruptor for 7 cycles at 30 seconds on and 90 seconds off, or a Covaris M220 Ultrasonicator for 60 seconds with a Peak Incidence Power of 50, Duty Factor of 10\%, and 200 cycles per burst. Samples were run out on a gel to verify sonication success.

Library preparation followed the general protocol of Starrett et al. (2017) and the UCE website (ultraconserved.org), with some modifications. Briefly, libraries were prepared using the KAPA Hyper Prep Kit (Kapa Biosystems), using up to 250 ng DNA (i.e., half reaction of manufacturer's protocol) as starting material. Ampure XP beads (Beckman Coulter) were used for all cleanup steps. For samples containing $<250 \mathrm{ng}$ total, all DNA was used in library preparation. After end-repair and A-tailing, $5 \mu \mathrm{M}$ universal adapter stubs (University of Georgia, EHS DNA Lab) were ligated onto libraries. Libraries were then amplified in a $50 \mu \mathrm{l}$ reaction, which consisted of $15 \mu \mathrm{l}$ adapterligated DNA, 1X HiFi HotStart ReadyMix, and $0.5 \mu \mathrm{M}$ of each Illumina TruSeq dualindexed primer (i5 and i7) with modified 8-bp indexes (Glenn et al. 2016). Amplification conditions were $98^{\circ} \mathrm{C}$ for $45 \mathrm{~s}$, then 16 cycles of $98^{\circ} \mathrm{C}$ for $15 \mathrm{~s}, 60^{\circ} \mathrm{C}$ for $30 \mathrm{~s}$, and $72{ }^{\circ} \mathrm{C}$ for $60 \mathrm{~s}$, followed by a final extension of $72^{\circ} \mathrm{C}$ for $60 \mathrm{~s}$. Samples were quantified to ensure amplification success. Equimolar amounts of libraries were combined into $1000 \mathrm{ng}$ pools consisting of eight samples each (125 ng per sample).

Target enrichment was performed on pooled libraries using the MYbaits Arachnida $1.1 \mathrm{~K}$ version 1 kit (Arbor Biosciences) following the Target Enrichment of Illumina Libraries v. 1.5 protocol (http://ultraconserved.org/\#protocols). Hybridization was conducted at $65^{\circ} \mathrm{C}$ for 24 hours, then libraries were bound to streptavidin beads (Dynabeads MyOne C1, Invitrogen) and washed. Following hybridization, pools were amplified in a $50 \mu \mathrm{l}$ reaction consisting of $15 \mu \mathrm{l}$ of hybridized pools, 1X Kapa HiFi HotStart ReadyMix, $0.25 \mu \mathrm{M}$ of each of TruSeq forward and reverse primers, and 5 $\mu \mathrm{l} \mathrm{dH} 20$. Amplification conditions consisted of $98^{\circ} \mathrm{C}$ for $45 \mathrm{~s}$, then 16 cycles of 98 ${ }^{\circ} \mathrm{C}$ for $15 \mathrm{~s}, 60{ }^{\circ} \mathrm{C}$ for $30 \mathrm{~s}$, and $72{ }^{\circ} \mathrm{C}$ for $60 \mathrm{~s}$, followed by a final extension of 72 ${ }^{\circ} \mathrm{C}$ for 5 minutes. Following an additional cleanup, libraries were quantified using a Qubit fluorometer. Molarity was determined with an Agilent 2100 Bioanalyzer and equimolar mixes were prepared for sequencing on an Illumina NextSeq (University of California, Riverside Institute for Integrative Genome Biology) with 150 bp PE reads. 


\section{Bioinformatic and phylogenomic analyses}

Raw demultiplexed reads were processed entirely in the PHYLUCE pipeline (Faircloth 2015). Quality control and adapter removal were conducted with the ILLUMIPROCESSOR wrapper (Faircloth 2013). Assemblies were created with TRINITY r2013-02-25 (Grabherr et al. 2011) and VeLvet 1.21 at default settings. For each sample, the fasta files from both assembly methods were combined into a single file. The combined assembly contigs were matched to probes using minimum coverage and minimum identity values of 65 with a modified version of the "phyluce_assembly_match_contigs_to_probes" script to allow multiple hits to a single probe. UCE loci were aligned with MAFFT (Katoh and Standley 2013) and trimmed with GBLOCKs (Castresana 2000, Talavera and Castresana 2007) with custom blocks settings ( $\mathrm{b} 1=0.5, \mathrm{~b} 2=0.5, \mathrm{~b} 3=6, \mathrm{~b} 4=6$ ) implemented in the PHYLuce pipeline. Individual UCE alignments were imported into Geneious 11.0.4 (http://www. geneious.com, Kearse et al. 2012) and manually inspected for obvious alignment errors and to remove any potential non-homologous sequences. In this case, ingroup sequences more divergent than outgroup taxa based on pairwise genetic distance calculated in Geneious were flagged and removed as potential non-homologs. Two datasets were produced including loci at two different taxon coverage thresholds ( $50 \%$ and $70 \%)$. All bioinformatic analyses were performed on a late $2015 \mathrm{iMac}$, except for contig assembly, which was run on the University of California, Riverside Institute for Integrative Genome Biology Linux cluster.

Analyses of both $50 \%$ and $70 \%$ datasets included concatenated maximum likelihood, concatenated Bayesian, and coalescent-based analyses, while partitioned maximum likelihood analyses were run only on the $70 \%$ dataset with partitions and models determined by PartitionFinder v1.1.1 (Lanfear et al. 2012). Maximum likelihood trees were estimated with RAxML v8.2 (Stamatakis 2014) using the rapid bootstrap algorithm, 500 bootstrap replicates, and the GTRGAMMA model. Bayesian analyses were conducted using the BEAST v2.4 package (Bouckaert et al. 2014), run for 100 million generations, logging every 1000 generations, with $10 \%$ burnin. To assess convergence, Tracer (Rambaut et al. 2007) was used to check for ESS values $>200$ and examine stationarity of parameters. Two separate analyses were run to check for convergence between runs. All RAxML and BEAST analyses were run through the CIPRES PORTAL (Miller et al. 2010). To incorporate coalescent approaches, ASTRAL-II (Mirarab et al. 2014, Mirarab and Warnow 2015) was used with individual gene trees estimated in RAxML, and SVDQuartets (Chifman and Kubatko 2014, 2015) was run through PAUP* 4.0a159 (Swofford 2003), with 100 bootstrap replicates.

\section{Results}

\section{Sequencing results}

Sequencing results and data matrix statistics are presented in Suppl. material 1. Raw sequence reads are available in the NCBI Short Read Archive Accession no. SRP142540 
(BioProject ID PRJNA451420). Untrimmed contigs, all trimmed individual locus alignments (pre- and post-manual editing), and trimmed concatenated matrices are available from the Dryad Digital Repository: http://dx.doi.org/10.5061/dryad.tj48997. Combining assemblies resulted in higher numbers of resulting UCE loci relative to using only a single assembly method, suggesting assembly-specific contigs as found in Hedin et al. (2018). The average number of UCE loci sequenced was 748 across all travunioid samples and 675 across all samples included in this study. The $70 \%$ taxon coverage matrix included 317 loci (272 average loci per sample, total length of 83,990 bp, 253.86 bp average locus length) and the $50 \%$ taxon coverage matrix included 677 loci (488 average loci per sample, total length of 165,096 bp, 264.95 average locus length).

\section{Phylogenomic analyses}

All analyses, with the exception of the $70 \%$ concatenated BEAST analysis, recover Travunioidea as sister group to all other Laniatores lineages (Figure 3 and Suppl. material 2: Figure 1), a relationship not recovered in previous molecular phylogenetic studies. However, based on morphological data, this hypothesis has been put forth by Kury (2015) who created the name Tricospilata Kury, 2015 for Triaenonychoidea + Grassatores (the sister group to Travunioidea). The $70 \%$ concatenated BEAST analysis recovers Travunioidea + Triaenonychoidea Sørensen, 1886 (= Synthetonychiidae + Triaenonychidae), previously called Insidiatores Loman, 1900, sister group to the Grassatores. The only other phylogenetic analysis resulting in Insidiatores as sister group to Grassatores is the transcriptome-based study of Fernández et al. (2016). Synthetonychiidae is recovered as sister group to Triaenonychidae with full support in all RAxML and SVDQuARTETS analyses and the concatenated BEAST analysis, but is sister group to all non-travunioid Laniatores (Triaenonychidae + Grassatores) in the ASTRAL analyses. It is apparent that denser taxonomic sampling and further phylogenomic datasets will be required to resolve the base of Laniatores.

Travunioidea is monophyletic and fully supported across all analyses (Figure 3). Within Travunioidea, no families (and all but one subfamily) as currently defined in Kury et al. (2014) are monophyletic in any analyses (Figs 4, 5). A highly supported sister relationship between Travunia and Trojanella is recovered, and this group is sister to all remaining travunioids in all analyses. The western North American genera Cryptomaster Briggs, 1969 and Speleomaster Briggs, 1969 are recovered as sister taxa, and although the placement of Cryptomaster + Speleomaster is inconsistent across analyses, they are never sister group to or included within the Travuniidae or Cladonychiinae sensu Kury et al. (2014). In all analyses, the traditional Briggsinae (Briggsus Özdikmen \& Demir, $2008+$ Isolachus Briggs, 1971) are recovered within a largely travuniid clade, and always the sister group to Speleonychia Briggs, 1974. Eastern North American Erebomaster Briggs, $1969+$ Theromaster Briggs, 1969 (traditional Cladonychiinae) is the sister group to the Briggsinae + Peltonychia clavigera (Simon, 1879) in all analyses. The two samples of the European genus Peltonychia Roewer, 1935 included in this study are never sister, P. leprieurii (Lucas, 1861) is found as the sister group to Holoscotolemon Roewer, 1915 while P. clavig- 


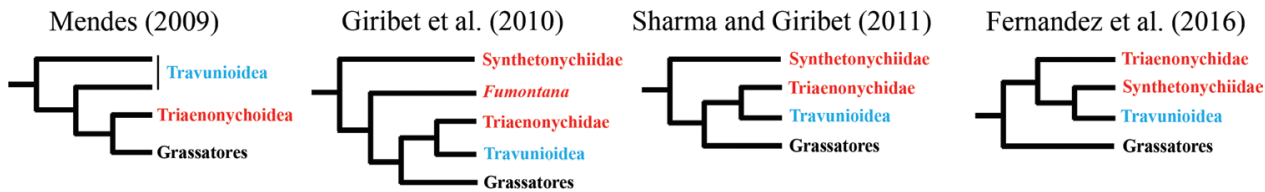

\section{RAxML/SVD/BEAST 50}

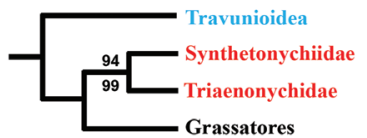

ASTRAL

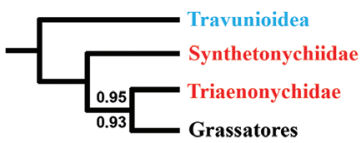

BEAST 70 concat

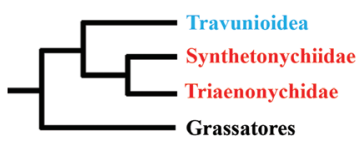

Figure 3. Phylogenetic relationships among major laniatorean lineages. Lower phylogenies correspond to results presented in this study. Nodes are fully supported (100\% bootstrap or 1.0 posterior probability), unless indicated otherwise. Numbers in lower left phylogeny correspond to support values from $50 \%$ RAxML concatenated (top), and from 70\% RAxML partitioned (bottom) analyses. Numbers in ASTRAL phylogeny based on 50\% (top) and 70\% (bottom) matrices.

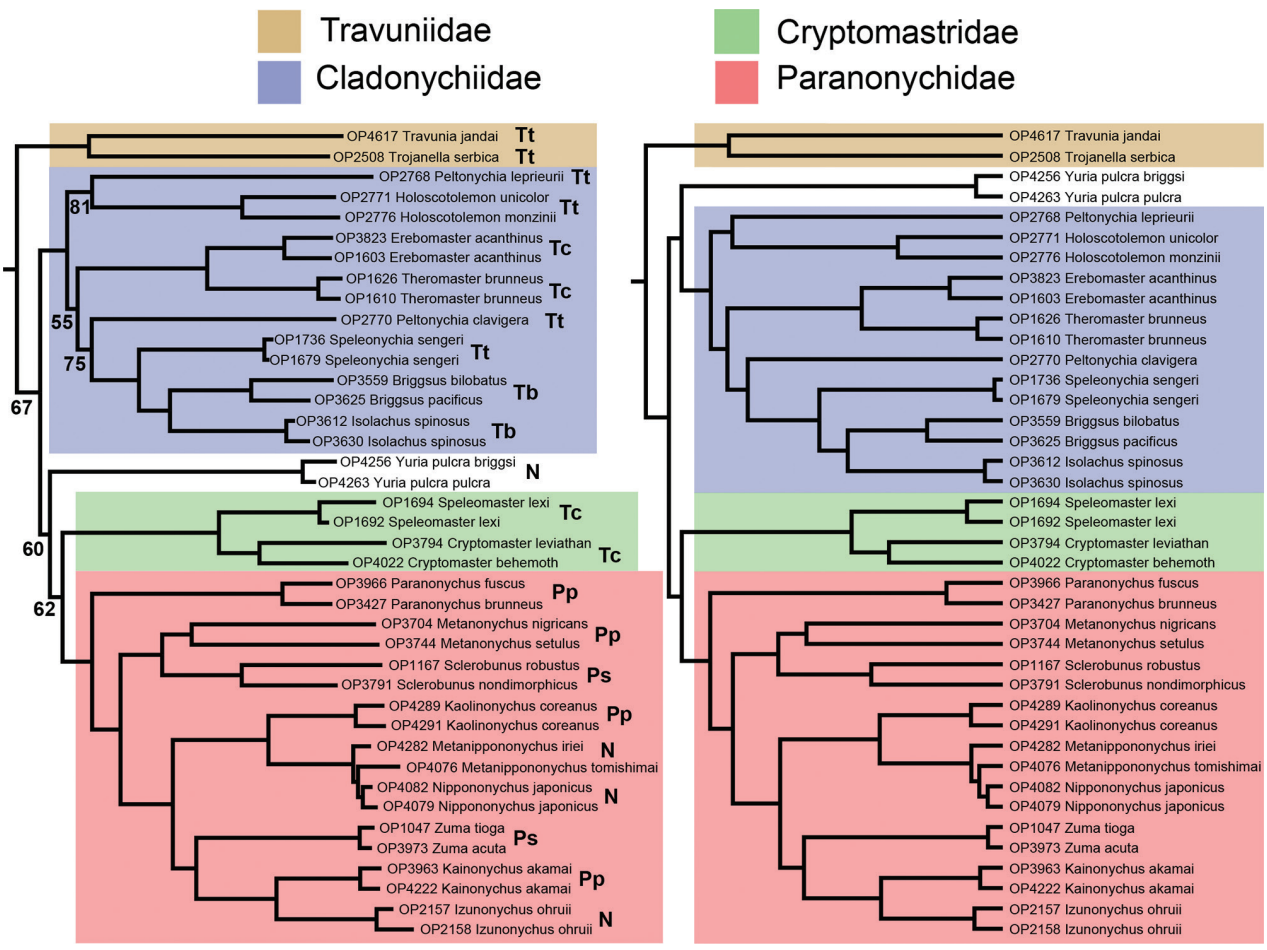

Figure 4. Phylogenomic relationships among travunioid genera. Left: RAxML and 50\% BEAST concatenated topologies, with bootstrap support from the partitioned analysis. All nodes in the BEAST topology have posterior probability of 1.0. Abbreviations indicate placement in classification at the time of Kury et al. (2014): $\mathrm{Tt}=$ Travuniidae, Travuniinae; $\mathrm{Tc}=$ Travuniidae, Cladonychiinae; $\mathrm{Tb}=$ Travuniidae, Briggsinae; Pp = Paranonychidae, Paranonychinae; Ps = Paranonychidae, Sclerobuninae; N = Nippononychidae. Right: $70 \%$ BEAST concatenated. Nodes are fully supported (100\% bootstrap or 1.0 posterior probability), unless indicated. 

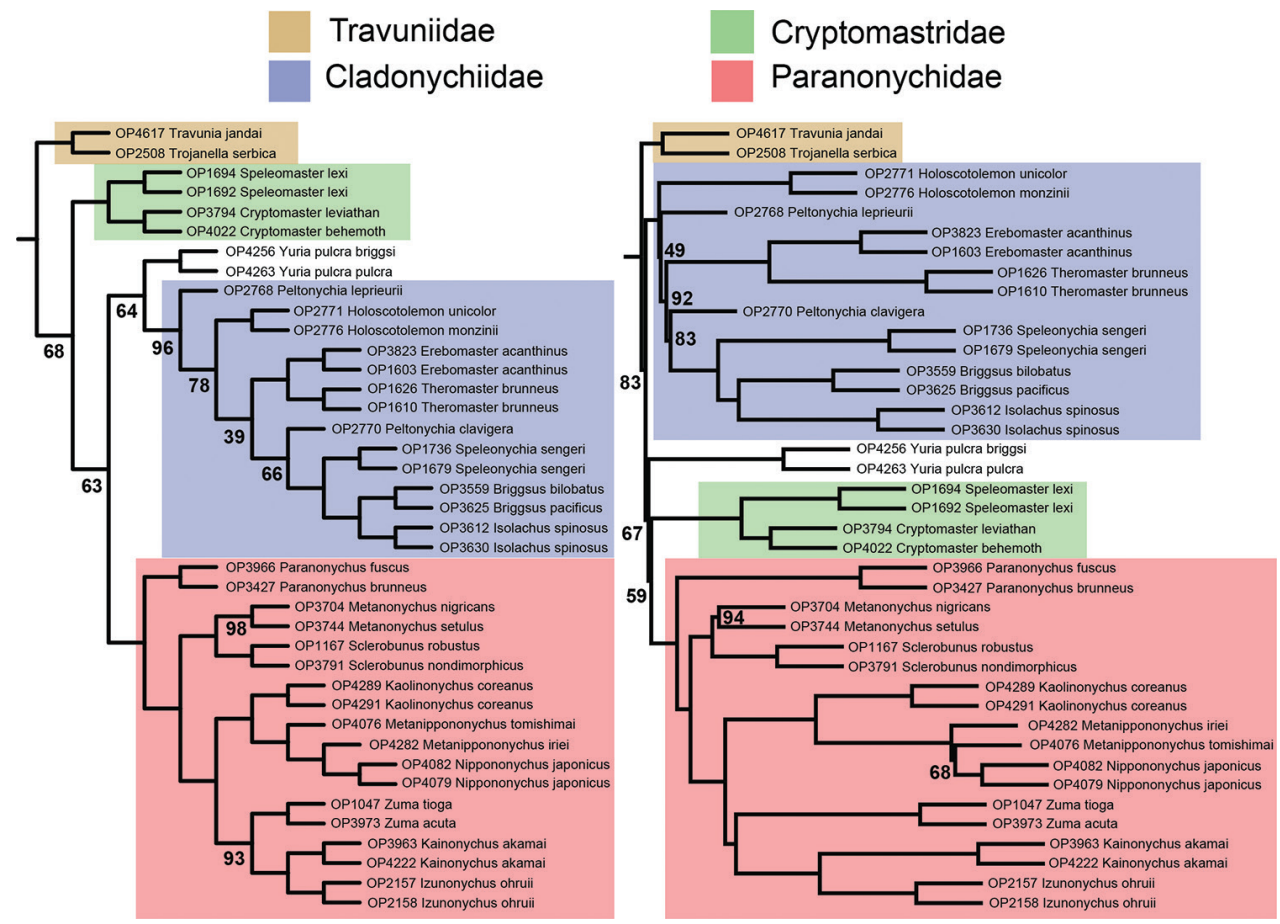

Figure 5. Phylogenomic relationships among travunioid genera. Left: 70\% SVDQUARTETs. Right: 70\% ASTRAL. Nodes are fully supported (100\% bootstrap), unless indicated.

era is the sister group to Briggsinae + Speleonychia. The relationships among these lineages are generally weakly supported at multiple nodes. All analyses recover a clade comprised of the former "northern triaenonychids", currently in the families Paranonychidae and Nippononychidae, although neither family as currently defined is monophyletic. The Californian endemic genus Zuma Goodnight \& Goodnight, 1942 is recovered within a clade comprised of Japanese taxa except Yuria Suzuki, 1964 and Paranonychus fuscus (Suzuki, 1976). The relationships within this lineage are all highly supported and identical across all analyses. The placement of the Japanese genus Yuria differs considerably across analyses and is recovered as the sister group to either the traditional travuniids or to a clade comprising Cryptomaster + Speleomaster and the Paranonychidae + Nippononychidae. Most importantly, Yuria is never recovered with the other Japanese nippononychids.

\section{Phylogenomic revision}

Our approach to establish a stable classification involved identifying the largest group of terminal taxa that are always monophyletic and always highly supported across all analyses. We discovered four multi-genus clades consistent across all analyses (Figs 4, 5), treated here as families: 
1) A clade containing Travunia + Trojanella. Because of the inclusion of Travunia, this clade retains the name Travuniidae.

2) A clade containing the majority of travuniid genera sensu Kury et al. (2014): Peltonychia, Holoscotolemon, Erebomaster, Theromaster, Speleonychia, Briggsus, and Isolachus. This clade will use the re-elevated and re-circumscribed familial name Cladonychiidae (see below).

3) A clade containing all genera currently included in the Paranonychidae and Nippononychidae of Kury et al. (2014). This clade retains the familial name Paranonychidae.

4) A clade consisting of the two former Cladonychiinae genera Cryptomaster and Speleomaster, endemic to the Pacific Northwest of North America, described below as the new family Cryptomastridae fam. n. (Figure 6).

The genus Yuria is considered incertae sedis given its uncertain phylogenetic placement (see Discussion). The new phylogenomics-based classification, used hereafter, is summarized in Table 2.

\section{Taxonomy}

Below we redefine and diagnose all families of Travunioidea, including the newly described Cryptomastridae. The unsampled European genera are placed into two of these families based on previous morphological studies: Dinaria is placed in the Travuniidae with Travunia and Trojanella, while Arbasus and Buemarinoa are placed in the Cladonychiidae with Peltonychia and Holoscotolemon. It is premature to discuss definitive morphological

Table 2. Proposed revised classification. The number of described species/subspecies at each taxonomic level is in parentheses. Genera are grouped by phylogenetic affinity, not alphabetically.

\begin{tabular}{|c|c|}
\hline \multicolumn{2}{|c|}{ Travunioidea $(69 /+11)$} \\
\hline Travuniidae (6) & Cryptomastridae (4) \\
\hline Dinaria $(1)$ & Cryptomaster (2) \\
\hline Travunia (4) & Speleomaster (2) \\
\hline \multicolumn{2}{|l|}{ Trojanella (1) } \\
\hline Cladonychiidae $(30 /+1)$ & Paranonychidae $(28 /+9)$ \\
\hline Arbasus (1) & Paranonychus (3) \\
\hline Buemarinoa (1) & Metanonychus $(3 /+5)$ \\
\hline Peltonychia (8) & Sclerobunus (12) \\
\hline Holoscotolemon (8) & Kaolinonychus $(1 /+1)$ \\
\hline Erebomaster $(3 /+1)$ & Metanippononychus $(4 /+2)$ \\
\hline Theromaster (2) & Nippononychus (1) \\
\hline Briggsus (5) & Zuma (2) \\
\hline Isolachus (1) & Kainonychus $(1 /+1)$ \\
\hline \multirow[t]{3}{*}{ Speleonychia (1) } & Izunonychus (1) \\
\hline & incertae sedis $(1 /+1)$ \\
\hline & Yuria $(1 /+1)$ \\
\hline
\end{tabular}


synapomorphies for all travunioids, as all hypothesized members have never been surveyed for all relevant morphological characters. However, likely morphological synapomorphies include the presence of a four-lobed ovipositor and a bipartite intestinal diverticulum tertium (OD3 below; Dumitrescu 1975, 1976, reviewed in Giribet and Kury 2007).

\section{Abbreviations used for intestinal diverticula}

D1 diverticulum 1;

OD2 opisthosomal diverticula 2;

OD3 opisthosomal diverticula 3.

Terminology and homology for penis/glans structure follows Martens (1986).

\section{Suborder LANIATORES Thorell, 1876}

Family CRYPTOMASTRIDAE Derkarabetian \& Hedin, fam. n. http://zoobank.org/A32A845F-36A7-426B-B3C1-F4E65085F356

\section{Type genus. Cryptomaster Briggs, 1969}

\section{Type species. Cryptomaster leviathan Briggs, 1969}

Diagnosis. The Cryptomastridae can be diagnosed from all other travunioids by the presence of a distal swelling on tibia II that bears enlarged setae (Figure 6A, C), a sexually dimorphic structure found only in males. Both genera are fairly distinctive. Cryptomaster is easily identified as the largest ( $>2.5 \mathrm{~mm}$ body length) laniatorean in the Pacific Northwest of North America (Figure 6D) and largest member of Travunioidea, although two size forms exist (Starrett et al. 2016). Speleomaster species are restricted to lava tubes showing extreme levels of troglomorphy with complete absence of eyes, extremely reduced pigmentation, and leg elongation (Figure 6B). Although unrelated, Speleomaster and Speleonychia are both highly troglomorphic lava tube dwellers in the Pacific Northwest, found in Idaho and Washington, respectively. Aside from their disjunct geographic distribution, Speleomaster can be differentiated from Speleonychia by the absence of a free ninth tergite and lateral sclerites, and by the presence of bifurcating tarsal claws of the hind legs (Speleonychia with a peltonychium). The cryptomastrid genera can be distinguished from the eastern North American Cladonychiidae (Erebomaster + Theromaster) by the spination of the pedipalpal tarsus, previously noted by Briggs (1969, 1974). Cryptomastrids possess five prominent spines on the lateral margins of the pedipalpal tarsus, three on the prolateral margin and two on the retrolateral margin. Erebomaster and Theromaster possess three pairs of prominent lateral spines (in some Theromaster, the two apical retrolateral spines are fused at the base). The Cryptomastridae are unique in intestinal morphology, possessing a combination of an elongate and triangular DI (similar to Briggsus and Isolachus), and shorter OD2 and OD3 (similar to the Paranonychidae) (Suppl. material 2: Figure 2). 

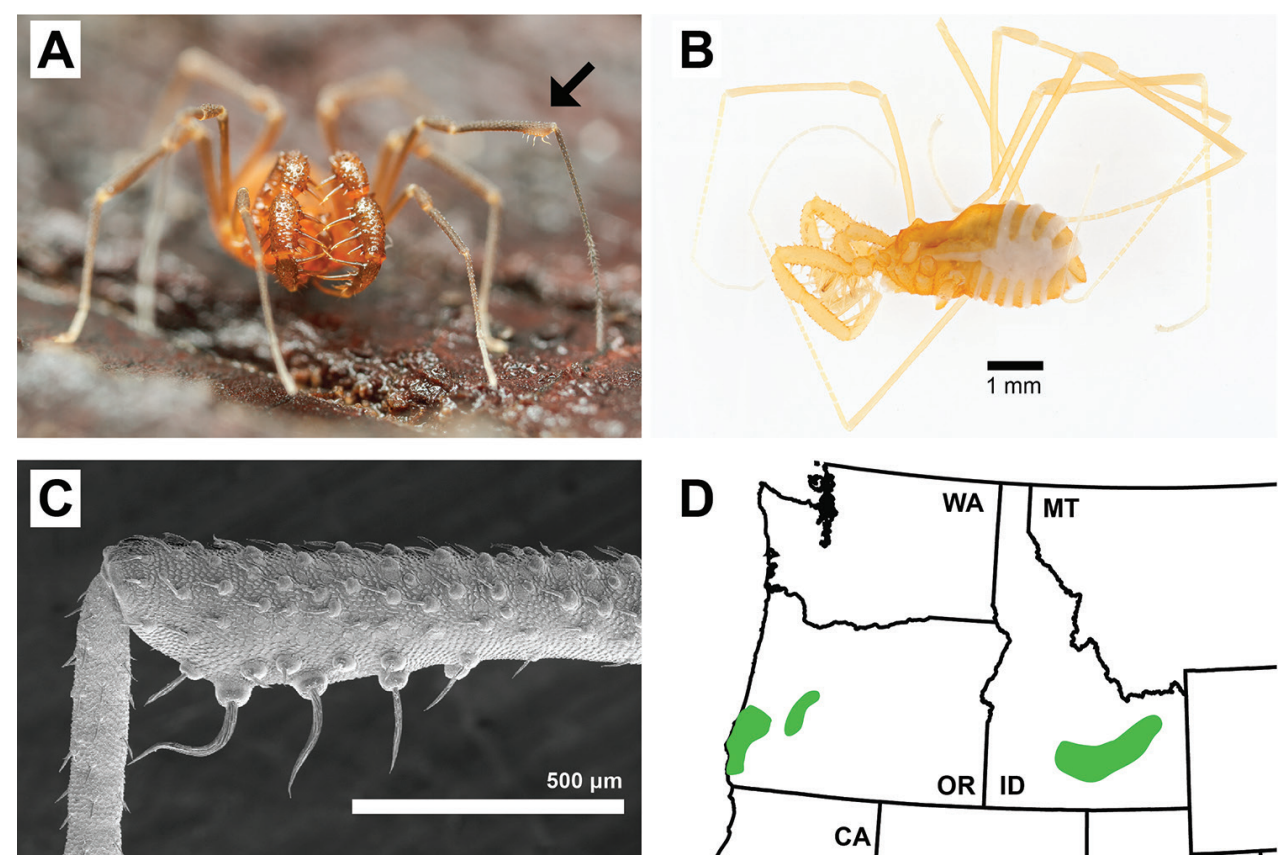

Figure 6. Morphology of Cryptomastridae. A) male Cryptomaster, arrow denotes sexually dimorphic swelling diagnostic of Cryptomastridae; B) Speleomaster, habitus; C) Scanning electron micrograph of tibial swelling, from Starrett et al. (2016); D) Cryptomastrid distribution.

Included genera and species. Cryptomaster. Described by Briggs (1969) and originally included only Cryptomaster leviathan Briggs, 1969 from the Coastal Range of southwestern Oregon. A second species, Cryptomaster behemoth Starrett \& Derkarabetian, 2016, was described from the west-central Cascade Range of Oregon (Starrett et al. 2016).

Speleomaster. Briggs (1974) described the genus and both known species, Speleomaster lexi Briggs, 1974 and Speleomaster pecki Briggs, 1974, from lava tubes of the Snake River Plain in southern Idaho.

\section{Family TRAVUNIIDAE Absolon \& Kratochvíl, 1932}

Type genus. Travunia Absolon, 1920.

Type species. Travunia troglodytes (Roewer, 1915).

Diagnosis. It is difficult to diagnose the Travuniidae as all taxa have yet to be examined for all relevant characters. For all species in which male genitalia have been examined, the glans is widened and flattened with lateral extensions, tooth-like in Trojanella and wing-like in Travunia and Dinaria. The Travuniidae as defined here are restricted to the European Dinaric Karst and are highly troglomorphic, completely blind with a highly reduced ocularium (Figure 1F). The penis of Travunia and Dinaria 
is undifferentiated, while that of cladonychiids shows a clear division between glans and shaft. Trojanella shows some similarities in glans structure to Holoscotolemon and Peltonychia (e.g., divided glans and shaft), but the penis musculature is restricted to the apical portion of the shaft and glans in Trojanella, while the musculature of the European cladonychiids are restricted to the basal portion of the shaft.

Included genera and species. Travunia. The genus Travunia includes four described species that are all highly troglomorphic and restricted to caves in the southern Dinaric Karst region of Europe: T. borisi (Hadži, 1973) from Bosnia and Herzegovina, T. hofferi (Šilhavý, 1937) from Montenegro, T. jandai Kratochvíl, 1937 from Croatia, and T. troglodytes (Roewer, 1915) from Croatia and Bosnia and Herzegovina.

Trojanella (Figure 1F). This monotypic genus is represented by T. serbica Karaman, 2005, a highly troglomorphic species restricted to a single cave on Stara Planina Mountain in Serbia.

Dinaria. A monotypic genus represented by the highly troglomorphic species $D$. vjetrenicae (Hadži, 1932) known only from Vjetrenica Cave in southern Bosnia and Herzegovina.

Remarks. It is not surprising that Trojanella is included in the most early-diverging travunioid lineage given Karaman's (2005) statement that this species is a "unique and isolated phylogenetic line in the superfamily". Karaman's decision to leave Trojanella unplaced in Travunioidea was made to highlight, and is a consequence of, the commonly used morphological characters that have hindered a reliable taxonomy within this group. It is unclear how many species of Travunia actually exist. Novak (2004) questioned the validity of Travunia, Dinaria, and Abasola at the generic level, and Abasola was later synonymized with Travunia (Kury and Mendes 2007). Novak $(2004,2005)$ argues that Travunia may be oversplit and includes only $2-3$ species of questionable status. The status of Travunia and Dinaria as distinct genera has been questioned based on similarity in male genitalic morphology (Novak 2004); together these might represent a single lineage.

\section{Family CLADONYCHIIDAE Hadži, 1935}

\section{Type genus. Erebomaster Briggs, 1969.}

Type species. Erebomaster flavescens Cope, 1872.

Diagnosis. Some taxa have not been examined for the relevant characters, but tentative diagnostic characters may be found in the intestinal complex (Suppl. material 2: Figure 2). All Cladonychiidae that have been examined show a 2-3 branched, elongate, and triangular D1, and elongate OD3. In the Pacific Northwest of North America, cladonychiids are broadly sympatric with the Cryptomastridae and Paranonychidae. The above intestinal characteristics differentiate them from Cryptomastridae, which possess a relatively short and stout OD3, and the Paranonychidae, which possess a simple unbranched D1 (Suppl. material 2: Figure 2). The European taxa can be diagnosed from Travuniidae based on male genital morphology (Figure 7): travuniids have a widened and flattened glans with lateral wing-like extensions; the glans and shaft are 


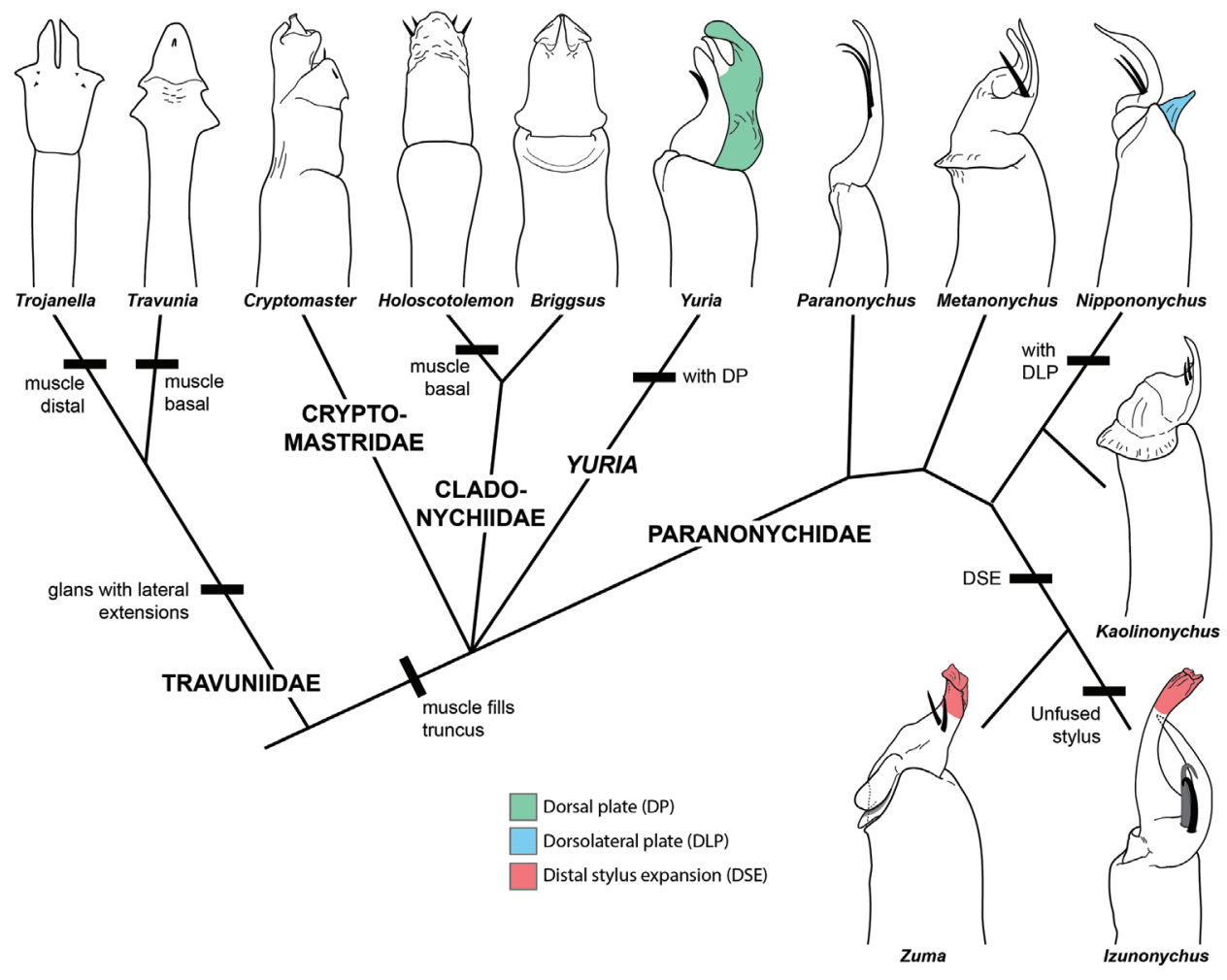

Figure 7. Representative penis morphology of Travunioidea. Clockwise from left: Trojanella serbica redrawn from Karaman (2005), Travunia hofferi redrawn from Karaman (2005), Cryptomaster behemoth adapted from Starrett et al. (2016), Holoscotolemon jaqueti redrawn from Martens (1978), Briggsus hamatus, Yuria pulcra, Paranonychus brunneus, Metanonychus setulus navarrus, Nippononychus japonicus redrawn from Suzuki (1975), Kaolinonychus coreanus coreanus redrawn from Suzuki (1975), Izunonychus ohruii, Zuma acuta. All Travuniidae and Cladonychiidae are drawn in ventral view; Cryptomastridae, Yuria, and Paranonychidae drawn in lateral. For simplicity, not all travunioid genera are included.

undivided in Travunia and Dinaria. The penis musculature is restricted to the base in Holoscotolemon and Peltonychia, while the musculature of Trojanella is restricted to the apical portion of the shaft and glans.

Included genera and species. Erebomaster (Figure 1B). Erebomaster is found in the eastern United States, and currently includes three species: E. flavescens Cope, 1872 with two subspecies E. f. flavescens from Wyandotte Cave in Indiana and E. f. coecus (Packard, 1888) from Carter Cave in Kentucky; E. weyerensis (Packard, 1888) from caves in West Virginia; and the relatively widespread E. acanthinus (Crosby \& Bishop, 1924) with a distribution along and west of the Appalachian Mountains. A revision of Erebomaster taxa is needed.

Theromaster (Figure 1A). Consisting of two described species found in the eastern United States: T. brunneus (Banks, 1902) is relatively widespread in the southern Appalachian Mountains; T. archeri (Goodnight \& Goodnight, 1942) from caves in Alabama. 
Speleonychia (Figure 1I). A monotypic genus, Speleonychia sengeri Briggs, 1974 is a highly troglomorphic species restricted to lava tubes near Mt. Adams, in southcentral Washington.

Briggsus (Figure 1G). The genus and all species were originally described by Briggs (1971b) as Pentanychus; Özdikmen and Demir (2008) provided the replacement name. This genus consists of five described species all restricted to the moist coastal forests (>50 inches yearly rainfall) of Oregon and Washington in the Pacific Northwest: $B$. bilobatus (Briggs, 1971), B. clavatus (Briggs, 1971), B. flavescens (Briggs, 1971), B. hamatus (Briggs, 1971), and B. pacificus (Briggs, 1971).

Isolachus (Figure 1H). A monotypic genus, Isolachus spinosus Briggs, 1971 is restricted to northwest Oregon and southwest Washington.

Holoscotolemon (Figure 1D). A European genus with eight species. Six species are restricted to the Alps, primarily from Italy and Austria: H. unicolor Roewer, 1915; H. lessiniensis Martens, 1978; H. oreophilus Martens, 1978; H. franzinii Tedeschi \& Sciaky, 1994; H. monzinii Tedeschi \& Sciaky, 1994; and H. naturae Tedeschi \& Sciaky, 1994. H. querilhaci (Lucas, 1864) is found in the Pyrenees of southern France and H. jaqueti (Corti, 1905) is recorded from eastern Europe in Romania, Ukraine, and former Yugoslavia.

Peltonychia (Figure 1E). A genus with a long history, Peltonychia includes the first described travunioid species, $P$. leprieurii. This genus of eight species is almost entirely known only from caves in central Europe throughout the Pyrenees and Alps (Suppl. material 2: Figure 3). Peltonychia leprieurii is found in the Alps of northern Italy. Peltonychia clavigera, P. navarica (Simon, 1879), P. piochardi (Simon, 1872), and P. sarea (Roewer, 1935) are all found in the Pyrenees of northern Spain and southern France. P. gabria Roewer, 1935 is recorded from Trieste, Italy; P. postumicola (Roewer, 1935) is recorded from eastern Italy and western Slovenia; and P. tenuis Roewer, 1935 is recorded from northern Slovenia. Records from Trieste, Italy and Slovenia are conclusively shown to be in error, and $P$. postumicola and $P$. tenuis are morphologically similar to $P$. clavigera (Novak and Gruber 2000). As such, it is unclear how many actual species are included.

Arbasus. A monotypic genus, the highly troglomorphic Arbasus caecus (Simon, 1911) is only known from Grotte de Pène Blanque in the Pyrenees of southern France.

Buemarinoa. A monotypic genus, the highly troglomorphic Buemarinoa patrizii Roewer, 1956 is only known from the Grotte del Bue Marino in Sardinia, Italy.

Proboloscotolemon Ubick \& Dunlop, 2005. A monotypic genus, P. nemastomoides (Koch \& Berendt, 1854) is known from specimens preserved in Baltic amber. The specimens were redescribed by Ubick and Dunlop (2005) and based on morphological similarity and geography it is interpreted as the ancestor of, or sister group to, Holoscotolemon.

Remarks. Peltonychia is polyphyletic, in some cases with strong support (Figure 5). The sampled species are from two separate geographic regions: $P$. clavigera from the Pyrenees of northern Spain and southern France, and P. leprieurii from the Alps of northern Italy. Accounting for the locality errors in Italy and Slovenia mentioned above, Peltonychia is geographically split into two regions: P. leprieurii in northern 
Italy, and the remaining species in the Pyrenees. The male genitalia of four species of Peltonychia have been examined: P. leprieurii, P. clavigera, P. gabria, and P. postumicola. Based on these genitalic drawings (Chemini 1985, Martens 1978, Thaler 1996), it is obvious that $P$. leprieurii is very divergent from the other three Peltonychia, which are very similar (Suppl. material 2: Figure 3). This concordance between geography, genital morphology, and our phylogenomic analyses support the separation of Peltonychia into two genera. However, we refrain from formally making this taxonomic change until all relevant species can be studied.

The sister relationship of Speleonychia to the traditional Briggsinae (Briggsus + Isolachus) is not surprising given the close geographic proximity of these genera and shared presence of a free ninth tergite and lateral sclerites. The distinct generic status of $\mathrm{Ar}$ basus and Buemarinoa has been doubted (Kury and Mendes 2007). The morphological distinction between Arbasus and Buemarinoa is minimal and entirely based on tarsal segmentation (Kury and Mendes 2007), which is typical of the "Roewerian classification" system that resulted in taxa being over split based on irrelevant characters (e.g., Kury et al. 2014, Kury and Pérez-González 2015). Aside from the original descriptions with basic drawings (Roewer 1935, 1956), virtually no taxonomic work has been conducted on Arbasus and Buemarinoa. However, Kury and Mendes (2007) note that they "both look superficially like Hadziani [=Peltonychia], but with clear troglomorphic traits...", and their inclusion in Cladonychiidae here seems justified.

\section{Family PARANONYCHIDAE Briggs, 1971}

\section{Type genus. Paranonychus Briggs, 1971}

Type species. Paranonychus brunneus (Banks, 1893).

Diagnosis. The Paranonychidae can be diagnosed by their relatively complex glans (except Paranonychus) (Figure 7 and Suppl. material 2: Figure 4), and by their intestinal complex (Suppl. material 2: Figure 2). For all taxa that have been examined, the paranonychids possess a small D1 that is circular to subtriangular, and a simple and shorter OD3. The paranonychids are restricted to western North America and East Asia. In southern Japan the paranonychids are sympatric with Yuria and can be diagnosed by several characteristics: Yuria possesses a free ninth tergite, and the penis has a dorsal plate with fused stylus; the paranonychids do not have a free ninth tergite and the penis glans lacks a dorsal plate. In western North America, the paranonychids are sympatric and syntopic in surface habitats with the Cladonychiidae (Briggsus, Isolachus) and Cryptomastridae (Cryptomaster). The paranonychids can be differentiated from these families by the structure of $\mathrm{D} 1$ : paranonychids possess a small circular to subtriangular unbranched D1, while Cladonychiidae and Cryptomastridae possess an elongate, triangular, and branched D1.

Included genera and species. Paranonychus (Figure $1 \mathrm{~K}$ ). This trans-Beringian genus includes three known species: P. brunneus (Banks, 1893) distributed in the Coast 
and Cascade Ranges of Oregon and Washington with records extending north to Alaska; P. concolor Briggs, 1971, recorded from a single location in the southern Cascade Range of Oregon; and P. fuscus found throughout northern Honshu in Japan.

Metanonychus Briggs, 1971. This genus and all species were described by Briggs (1971) and are restricted to the moist forests of the Pacific Northwest of North America. Metanonychus includes three species: M. nigricans Briggs, 1971 with two subspecies, M. n. nigricans and M. n. oregonus, found in Oregon; M. setulus Briggs, 1971 with five subspecies, M. s. setulus, M. s. cascadus, M. s. mazamus, M. s. navarrus, and $M$. s. obrieni, found in Oregon, Washington, and northern California; and M. idahoensis Briggs, 1971 found in northern Idaho.

Sclerobunus Banks, 1893 (Figure 1L). Recently revised by Derkarabetian and Hedin (2014), Sclerobunus is distributed throughout western North America and currently includes 12 species divided into three species groups. The nondimorphicus group includes S. nondimorphicus Briggs, 1971 from Oregon, Washington, and British Columbia, and S. idahoensis Briggs, 1971 from northern Idaho. The caveobligate cavicolens group includes: Sclerobunus cavicolens (Banks, 1905) restricted to Lewis and Clark Caverns, Montana; Sclerobunus ungulatus (Briggs, 1971) from caves in Great Basin National Park, Nevada; Sclerobunus madhousensis (Briggs, 1971) from caves near Provo, Utah. The robustus group includes the widespread S. robustus (Packard, 1877), S. glorietus Briggs, 1971, and S. skywalkeri Derkarabetian \& Hedin, 2014, all distributed throughout the high elevation forests of the southwestern United States, and S. jemez Derkarabetian \& Hedin, 2014, S. klomax Derkarabetian \& Hedin, 2014, S. speoventus Derkarabetian \& Hedin, 2014, and S. steinmanni Derkarabetian \& Hedin, 2014, which are all troglomorphic species restricted to cave and talus habitats along the eastern edge of the southern Rocky Mountains in New Mexico and Colorado.

Kaolinonychus Suzuki, 1975. This monotypic genus endemic to South Korea is recorded mostly from caves. Kaolinonychus coreanus (Suzuki, 1966) includes two subspecies $K$. c. coreanus and $K$. c. longipes.

Metanippononychus Suzuki, 1975. (Figure 1M). Endemic to Japan, Metanippononychus is restricted to southern Honshu, Shikoku, and Kyushu and includes four species: $M$. daisenensis Suzuki, 1975; M. iriei Suzuki, 1975, with two subspecies M. i. iriei and M. i. yakuensis; M. iyanus Suzuki, 1975; M. tomishimai Suzuki, 1975, with two subspecies $M$. t. tomishimai and $M$. t. awanus.

Nippononychus Suzuki, 1975. A monotypic genus endemic to Japan, Nippononychus japonicus (Miyosi, 1957) is restricted to southern Honshu and Shikoku.

Zuma (Figure 1N). Zuma includes two species restricted to forests of central and northern California: Zuma acuta Goodnight \& Goodnight, 1942 restricted to the coastal forests south of San Francisco; Zuma tioga Briggs, 1971 found in the central and northern Sierra Nevada range.

Izunonychus Suzuki, 1975. A monotypic genus endemic to Japan, Izunonychus ohruii Suzuki, 1975 is restricted to the Izu peninsula and Hakone area in central Honshu. 
Kainonychus Suzuki, 1975 (Figure 1O). A monotypic genus endemic to Japan, Kainonychus akamai (Suzuki, 1972) includes two subspecies, K. a. akamai distributed throughout northern Honshu and $K$. a. esoensis restricted to Hokkaido.

Remarks. In this study all genera in the Paranonychidae have been sampled and the generic relationships are consistent and highly supported across all analyses (Figs 4, 5). Although the study of Derkarabetian et al. (2010) only included North American taxa, the relationships of paranonychids recovered here are the same, notably Paranonychus as the earliest diverging genus, and a sister relationship between Sclerobunus and Metanonychus. The familial name Sclerobunidae has been used previously (Giribet et al. 2010) for the "northern triaenonychids". However, Paranonychidae and the subfamily Paranonychinae Briggs, 1971 have priority over the names Sclerobunidae and Sclerobuninae Dumitrescu 1976.

The Japanese genera Metanippononychus and Nippononychus show levels of UCE divergence consistent with congeners (Figs 4, 5). Intermediate morphological forms between Nippononychus japonicus and Metanippononychus daisenensis can be found where the two species come into contact (Tsurusaki pers. obs.). These genera are differentiated only by tarsal claw structure: Metanippononychus possessing a ventral tooth on the median prong of the hind claws. The original drawings of male genitalia show that $M$. daisenensis and N. japonicus differ in the width of the stylus (Suzuki 1975b). However, the penis of $N$. japonicus is highly similar to that of the geographically proximate M. tomishimai tomishimai.

Kury et al. (2014) includes Paranonychus fuscus (formerly Mutsunonychus fuscus) as a synonym of Paranonychus brunneus (Banks, 1893) based on Shear's (1986) statement "Paranonychus brunneus (=Mutsunonychus fuscus Suzuki; Paranonychidae)". Later in Shear and Derkarabetian (2008), the genus Mutsunonychus was formally synonymized under Paranonychus, and although a potential species level synonymy was noted, it was not formally established. The levels of UCE divergence between P. brunneus and P. fuscus are consistent with species level divergences compared to other pairs of congeneric taxa included (Figs 4 and 5), and as such, P. fuscus is again treated as a distinct species here.

\section{Incertae sedis}

Included genera and species. Yuria (Figure 1J). A monotypic genus endemic to Japan, Yuria pulcra Suzuki, 1964 includes two subspecies distributed throughout southern Honshu, Shikoku, and Kyushu: Y. p. pulcra and Y. p. briggsi Suzuki, 1975.

Remarks. When Yuria pulcra was first described it was placed in Travuniidae because the tarsal claw is a peltonychium (Suzuki 1964, 1975a). Phylogenetic analysis of morphological data placed Yuria as the sister group to Nippononychus (Paranonychidae) with two synapomorphies (Mendes 2009). Kury et al. (2014) later transferred this genus to the Nippononychidae, which contained most of the other Japanese travunioids. 
Placement and support for Yuria varies depending on analysis (Figs 4, 5). Morphology complicates matters further, as Yuria possesses a free ninth tergite and lateral sclerites, plesiomorphic characters that are potentially neotenic and shared with the Briggsinae. The penis morphology of Yuria is also relatively unique within Travunioidea, possessing a dorsal plate with fused stylus (Figure 7 and Suppl. material 2: Figure 4).

\section{Discussion}

\section{Travunioidea classification and the trouble with travuniids}

Travunioidea includes 80 nominal taxa (species/subspecies), four families, and one unplaced genus. Traditionally within Travunioidea the subfamilial rank has been used to further subdivide taxa, and the composition of subfamilies has changed across classification schemes (Table 1). Here, we refrain from using the subfamilial rank for three reasons: 1) the confusing taxonomic history of these lineages, specifically with regards to relative rank and composition; 2) the poorly supported nodes in Cladonychiidae and non-monophyly of Peltonychia; 3 ) and the relatively sparse composition each subfamily would have (i.e., 4/6 subfamilies would contain only 1-2 genera). Based on phylogenomic analyses, the composition of all subfamilies would have changed again (Table 2). Relationships among several traditional Travuniidae genera are still uncertain, and the absolute stability of the familial rank will be dependent upon future incorporation of the unsampled European genera Arbasus and Buemarinoa.

The traditional Travuniidae have had an incredibly long and complex taxonomic history beginning with the description of the first travunioid in 1861. Kury and Mendes (2007) focus entirely on nomenclatural issues, resolving them at the familial and generic level, and in doing so note that "the [traditional] family Travuniidae constitutes one of the worst problems of the laniatorid taxonomy of the $20^{\text {th }}$ century". Several others have discussed the diverse array of problems plaguing travunioid taxonomy (Novak 2005, Novak and Gruber 2000, Karaman 2005). These issues include, but are not limited to, description of two species in two different genera based on the same material, autosynonymy of a genus name, proposal of unavailable family and genus names, genus description without designation of type species after 1930, species descriptions based on juveniles, mistranslation of foreign languages, disregard for correct taxonomic changes, mismatched type localities, type localities accidentally and intentionally incorrectly named, inability to find further specimens from type localities, and destruction of type localities. Even though the European taxa have received significant attention from a taxonomic standpoint, a great deal of focused and devoted research including fieldwork, and modern morphological and phylogenetic analyses will be needed to fully resolve the taxonomic issues of this notoriously difficult clade.

The goal of this research was to provide a stable classification of Travunioidea at the familial level. This stability relies on incorporating potential future changes if unsam- 
pled taxa are included. We believe our familial level classification, disuse of subfamily rank, and leaving Yuria unplaced, minimizes future taxonomic changes. All familial name-holding genera are included. Only Arbasus and Buemarinoa are missing but given morphological similarities and the geographic distribution of these taxa, their inclusion in Cladonychiidae given future sampling seems likely. The stability of the familial level provided by this phylogenomics-based reclassification and the recovered distinction between Travuniidae and European Cladonychiidae can guide future efforts. The morphologically enigmatic Yuria remains phylogenetically elusive. A potential solution to the unreliable placement of Yuria is to create a monotypic family. However, we refrain from this until all genera can be included in phylogenomic analyses.

\section{Morphological reevaluation}

The tarsal claw - A type of modified tarsal claw termed a peltonychium united the "traditional Travuniidae", a structure now known to be convergent in several unrelated cave-dwelling taxa (e.g., Peltonychia, Speleonychia, Trojanella). The morphological distinction between the typical trident-shaped tarsal claw (with variable number of sidebranches) and a peltonychium is not entirely clear in some travunioids (e.g., Izunonychus, Metanippononychus), and the transition between forms is best documented in the triaenonychid genus Lomanella Pocock, 1902 (Hunt and Hickman 1993). However, all of the 18 travunioid species (not including subspecies) with a clear peltonychium are found in caves, 10 of which are either described to be troglobitic (cave-obligate) and/or show high levels of troglomorphy. An additional six species are described to have reduced pigmentation (relative to surface-only species), five of which are only reported from caves. Two remaining species are inconsistent with this pattern. First, Peltonychia leprieurii, from the Alps of northern Italy and Switzerland is recorded from both cave and surface habitats (considered a troglophile) and retains black pigment. Second, $Y$. pulcra pulcra and $Y$. p. briggsi from southern Japan show some reduced pigmentation, though they differ in their habitat: $Y . p$. pulcra is recorded from both cave and surface habitats, while $Y . p$. briggsi is known only from surface habitats under woody debris. It has been suggested that the peltonychium, and other plesiomorphic characters, are convergent through neoteny (Rambla 1980, Hunt and Hickman 1993, Karaman 2005). The hind tarsal claws of juvenile triaenonychids and travunioids have more side branches than adults (e.g., Hunt and Hickman 1993, Suzuki 1975b), and some juveniles additionally possess a pseudonychium (median tarsal claw) (Shultz and Pinto-da-Rocha 2007, Gnaspini 2007). As such, the peltonychium may be a retained adult form of this juvenile structure (Hunt and Hickman 1993).

The ninth tergite and lateral sclerites - The traditional Briggsinae (Briggsus + Isolachus) were hypothesized to be a relatively early diverging lineage within Travunioidea (Briggs 1971, Giribet and Kury 2007). This was due to the presence of a free ninth tergite, and lateral sclerites, a plesiomorphic condition found in the other suborders of harvestmen. Conversely, penis morphology suggested that this group is derived given 
the relatively simple penis structure (Martens 1986). Speleonychia also possess a distinct ninth tergite and lateral sclerites, now shown to be a shared condition with Briggsus + Isolachus. Rambla (1980) argued that these characters are neotenic, retained in adults from nymphal stages, and as such are derived. All phylogenomic analyses here support the derived nature of these characters, as they are recovered well within the Cladonychiidae in all analyses. However, not all travunioid taxa with a free ninth tergite and free lateral sclerites are restricted to this clade, as Yuria also possess both characters (Suzuki 1964, 1975a). While the placement of Yuria is uncertain, it is never recovered with or as the sister group to the traditional Briggsinae + Speleonychia. Outside of Travunioidea, the only other laniatorean taxa known to possess free lateral sclerites are in the genus Hickmanoxyomma Hunt, 1990, a largely cave-dwelling triaenonychid genus endemic to Tasmania (Hunt 1990). In this genus the presence of five pairs of free lateral sclerites (2-3 in travunioids) are a diagnostic character for the H. cavaticum species group containing four species, all recorded only from caves and some showing troglomorphy. Hunt (1990) suggested it might be correlated with the overall reduced sclerotization associated with troglomorphy, but also reiterated Rambla's (1980) view of neoteny. No clear phylogenetic, evolutionary, or ecological pattern exists for these characters and their presence in multiple unrelated lineages suggests their plesiomorphic nature.

The midgut - Studies focusing on the digestive tract began in the 1920s, but the work of Dumitrescu (e.g., 1974, 1975, 1976) contributed most significantly to the phylogenetic utility of midgut morphology in Opiliones. Through examination of intestinal morphology Dumitrescu $(1975,1976)$ noticed the "northern triaenonychids" are more similar to the Travuniidae as they share a bipartate OD3, instead of the southern hemisphere triaenonychids (3-branched). As such, he placed the "northern triaenonychid" taxa into the family Paranonychidae Briggs, 1971. The name Paranonychidae was used by a few subsequent authors (e.g., Shear 1982, 1986, Ubick and Dunlop 2005), but from a classification standpoint, was not incorporated into the taxonomy as the taxa were left in the Triaenonychidae (e.g., Kury 2003a, Pintoda-Rocha and Giribet 2007; Kury 2007b). Later, molecular phylogenetic studies also showed the "northern triaenonychids" being grouped with the travunioid families (Giribet et al. 2010, Hedin and Thomas 2010, Derkarabetian et al. 2010, Sharma and Giribet 2011), and the familial name Paranonychidae was finally included in Opiliones taxonomy by Kury (2013).

Our phylogenomic analyses allow for a reexamination of the intestinal morphology research of Dumitrescu $(1975,1976)$ (Suppl. material 2: Figure 2). First, the recovery of Travunioidea as the earliest diverging Laniatores lineage is reflected in the branching pattern of OD3. All Travunioidea possess an OD3 with two branches, a characteristic shared with the other harvestmen suborders, while the Synthetonychiidae, Triaenonychidae, and Grassatores possess three branches. This phylogenetic utility of OD3 was also noted in the morphological analyses of Mendes (2009), who recovered Travunioidea as the earliest diverging lineage of Laniatores. The intestinal complex also shows some phylogenetic value within Travunioidea; three of four families can be differentiated entirely based on intestinal morphology. Of the taxa examined by Dumitrescu 
(1975, 1976), the paranonychids possess a simple and circular D1 with no branches, while all cladonychiid genera possess a relatively complex D1 with 2-3 branches or is distinctly triangular in shape. Karaman (2005) also reports a D1 with two branches for Trojanella. Cryptomastridae possess a triangular D1, but the shorter OD2 and OD3 are more similar to those of the paranonychids. Samples of Briggsus and Speleonychia were included and look very similar to each other, particularly the D1, which is recorded to be 3-branched in Briggsus and triangular in Speleonychia (Dumitrescu 1976). Dumitrescu did not note the similarity, instead stating Speleonychia was most similar to Nippononychus japonicus (then Peltonychia japonica, placed in Travuniidae), perhaps subjectively limited by the classification system of the time. It is clear that there is phylogenetic utility in midgut morphology at higher taxonomic levels, and further descriptions are needed to confirm the consistency of diagnostic characteristics noted here.

The penis - Based on descriptions and drawings, the musculature and glans complexity can be used to diagnose and differentiate travunioid lineages recovered here (Figure 7) (Briggs 1971b, Suzuki 1975a, 1975b, Martens 1986, Karaman 2005, Novak 2005, Pinto-da-Rocha and Giribet 2007, Derkarabetian and Hedin 2014, Starrett et al. 2016). In Travunioidea, the glans is relatively simple and plate-like without dorsal, dorsolateral, or ventral plates in Trojanella, Travunia, Cryptomastridae, and Cladonychiidae, while in Yuria and Paranonychidae (except Paranonychus) the glans is relatively complex, and some possess a dorsolateral plate. The dorsal plate is absent from all travunioids, except Yuria, which possesses a dorsal plate that is fused to the stylus.

Given the consistent and highly supported relationships within Paranonychidae, diagnostic differences of paranonychid lineages can be seen in penis morphology (Figure 7; Suppl. material 2: Figure 4). Within Paranonychidae, the earliest-diverging genus Paranonychus possesses the simplest glans. Dorsolateral plates are present but reduced in two pairs of sister genera Sclerobunus + Metanonychus and Metanippononychus + Nippononychus (Briggs 1971b, Suzuki 1975b, Derkarabetian and Hedin 2014). Additionally, Sclerobunus + Metanonychus show a distinct setae-bearing process similar to a ventral plate ("sensillenträger" of Martens) that is fused to the base of the stylus in the Zuma + Japanese taxa. The Zuma + Izunonychus + Kainonychus clade possesses a modified stylus that is expanded distally (Briggs 1971b, Suzuki 1975b). As opposed to other Japanese paranonychids which have a stylus that is fused to the ventral plate, the stylus of both Izunonychus + Kainonychus is separated from the ventral plate (Suzuki 1975b).

The overall trend across Opiliones suborders is one of apparently increasing genitalic complexity. The earliest-diverging suborder Cyphophthalmi has a spermatopositor, the Dyspnoi and Eupnoi have a simple penis with relatively little modifications, and the derived Laniatores possess the most complex penes (Macías-Ordóñez et al. 2010). Within Laniatores the trend of increasing complexity is maintained, as Travunioidea with relatively simple glans morphology is possibly the most early-diverging Laniatores. Travunioidea and Triaenonychoidea use muscles for glans expansion (Shultz and Pinto-da-Rocha 2007, Pérez-González and Werneck 2018), a condition shared 
with Eupnoi and Dyspnoi. Relative to travunioids, the synthetonychiids and triaenonychids have slightly more complex glans structures with dorsolateral plates. Finally, in the most diverse laniatorean lineage Grassatores, muscles are absent, and the glans requires hydraulic pressure to expand (Shultz and Pinto-da-Rocha 2007). In Travunioidea, Martens (1986) noted a tendency towards simplification of the glans, and Karaman (2005) additionally noted a correlation where simplification of the glans structure is associated with reduction of penis musculature to basal portion of the truncus. Both Martens and Karaman argued that the simple glans of travunioids (i.e., traditional travuniids) is a derived condition, as all Triaenonychoidea have relatively complex glans with dorsolateral plates and a distinct process bearing setae, two characters lost in many travunioids. Most phylogenomic analyses conducted here recover Travunioidea as the most early-diverging Laniatores lineage suggesting a trend of simple to complex penis structure. It is interesting to note that the simplest glans and some taxa with relatively reduced musculature are found in cave-inhabiting taxa (e.g., Trojanella, Dinaria, Travunia), which may be a potential confounding factor in establishing a clear evolutionary trend. More detailed morphological examinations of the male and female genitalia using modern approaches (e.g., Pérez-González and Werneck 2018) will help elucidate evolutionary trends and provide more diagnostic characters for the families established here.

\section{Context for future research}

This phylogenomic study provides a more stable taxonomy for Travunioidea, which serves as a starting point for species-level phylogenomics and provides the phylogenetic context to explore evolutionary questions relating to character evolution, alpha taxonomy, and biogeography.

Morphological and chemical evolution - Many Travunioidea are cave-obligate taxa with species from 14 genera showing some degree of troglomorphy, possessing homoplastic morphological features that evolve as a response to cave life. Travunioidea can be an excellent system to study the repeated evolution of troglomorphy, as it has evolved at multiple taxonomic levels (e.g., within families, genera, species) with multiple independently derived taxa showing varying degrees of troglomorphy. For example, within the genus Sclerobunus, troglomorphy has evolved at least five times independently across multiple species and within single species and is time-correlated (Derkarabetian et al. 2010, Derkarabetian and Hedin 2016). A species-level phylogeny for all travunioids would allow for an accurate estimate of the number of independent evolutions of troglomorphy and allow for in-depth morphological analyses exploring the rate and timing of this potentially adaptive morphology, as well as providing the phylogenetic framework for comparative studies (e.g., gene expression).

Similarly, chemical evolution can be explored in this phylogenomic context. Harvestmen possess repugnatorial glands, which are used to store chemical cocktails that are secreted in defensive behavior. Chemical composition across lineages has been 
shown to have some phylogenetic value, particularly in Laniatores (Raspotnig 2012, Raspotnig et al. 2015). Similarly, a study focusing on Travunioidea and Triaenonychoidea has shown high levels of divergence in chemical composition between taxa formerly united under the traditional taxonomy (i.e., Cladonychiidae) (Shear et al. 2014). Given the phylogenetic context, detailed chemical analyses can be used to discover novel chemicals, compare pathways of identical chemicals found in independent lineages, and explore the evolution of biochemical pathways across taxa (e.g., Rodriguez et al. 2018).

Biogeography and alpha taxonomy - Cryophilic harvestmen are useful in biogeographic analyses because of restricted ecological constraints and extremely low vagility. Previous molecular phylogenetic studies on harvestmen with these biological characteristics have shown compelling biogeographic patterns (e.g., Boyer et al. 2007, Thomas and Hedin 2008, Giribet et al. 2011, Schönhofer et al. 2015, Boyer et al. 2015). The Travunioidea have a temperate Laurasian distribution with species found in eastern Asia, eastern and western North America, and central Europe, with notable absences from central Asia (Figure 2). Recent divergence dating analyses show an ancient origin of Travunioidea dating to $>200$ million years (Giribet et al. 2010, Sharma and Giribet 2011), although these time estimates should be revisited. Several travunioid lineages show trans-continental distributions. For example, members of the Cladonychiidae are distributed in Europe and eastern and western North America, while the Paranonychidae show a Beringian distribution with genera in western North America, Japan and South Korea. Many other harvestmen show similar broad distributions within the Holarctic including the Sironidae, Caddo, Leiobunum, and many Dyspnoi (Suzuki 1972b, Suzuki et al. 1977, Shultz and Regier 2009, Hedin et al. 2012a, Hedin et al. 2012b, Schönhofer et al. 2013).

The biological characteristics of essentially all travunioids are quite similar (e.g., dispersal-limited, restricted to cryophilic microhabitats in north temperate latitudes). Regional clades are relatively ancient, allowing ample time for the accumulation of species diversity. In addition, the presence of rare, completely blind, troglobitic species in several different geographic areas speaks to the ancient origin of the Travunioidea. It is likely that troglobitic species, especially those in central Europe, have an unknown diversity concealed by troglomorphy. Similarly, many ancient lineages can be found in the moist, coastal forests of the Pacific Northwest of North America (Briggsus, Metanon$y$ chus) that have likely persisted in refugia through climatic cycles. Additionally, all of these taxa consist of species and subspecies that are short-range endemics (Harvey 2002). Congeneric species syntopy is rare, probably because of ecological niche conservatism that prevents resource partitioning. This ecological niche conservatism likely plays an important role in speciation (see model of Wiens 2004). As such, there is a high potential for species discovery, and recent species-level studies focusing on the travunioid genera Sclerobunus and Cryptomaster have resulted in the description of new species (Derkarabetian and Hedin 2014, Starrett et al. 2016). Our ongoing studies of Travunioidea are continuing this trend: every genus currently being revised (Briggsus, Erebomaster, Theromaster, Metanonychus) shows evidence for new species. 


\section{Acknowledgements}

We thank the following people and institutions for specimens used in genetic analyses and/or for use of live-specimen photos: southern hemisphere Triaenonychidae, Synthetonychiidae, and Hinzuanius specimens were made available by Charles Griswold (California Academy of Sciences); Holoscotolemon samples and photos of Holoscotolemon and Peltonychia were provided by Axel Shönhofer; a specimen and photo of Trojanella serbica were provided by Ivo Karaman; and a specimen of Travunia jandai was provided by Martina Pavlek. For assistance in collecting North American travunioids, we thank Casey Richart, Allan Cabrero and Erik Ciaccio. We also thank Allan Cabrero for providing SEM images of Briggsus. Much of the early taxonomic literature referenced in this study was acquired through the OmniPaper Project (Kury 2003b) maintained by the tireless efforts of Adriano Kury. We are indebted to Brant Faircloth for initial training in UCE laboratory procedures at Louisiana State University, and for follow-up discussions regarding laboratory work and bioinformatic processing. Funding for this project was provided by an NSF grant (DEB \#1354558) to MH, an NSF Doctoral Dissertation Improvement Grant (DEB \#1601208) to SD, the American Arachnology Society Vincent Roth Fund for Systematics to SD, and JSPS KAKENHI grants (\# 19570086, 2644021 and $17 \mathrm{~K} 07534)$ to NT. The manuscript was improved by comments from Gonzalo Giribet, Prashant Sharma, Bill Shear, and one anonymous reviewer.

\section{References}

Absolon K, Kratochvíl J (1932) Peltaeonychidae, nova čeled slepých opilionidu z jeskýn jihoillyrské oblasti. Príroda 25: 153-156.

Baca SM, Alexander A, Gustafson GT, Short AE (2017) Ultraconserved elements show utility in phylogenetic inference of Adephaga (Coleoptera) and suggest paraphyly of ' $\mathrm{Hy}$ dradephaga'. Systematic Entomology 42: 786-795. https://doi.org/10.1111/syen.12244

Blaimer BB, Brady SG, Schultz TR, Lloyd MW, Fisher BL, Ward PS (2015) Phylogenomic methods outperform traditional multi-locus approaches in resolving deep evolutionary history: a case study of formicine ants. BMC Evolutionary Biology 15: 271. https://doi. org/10.1186/s12862-015-0552-5

Bouckaert R, Heled J, Kühnert D, Vaughan T, Wu CH, Xie D, Suchard MA, Rambaut A, Drummond AJ (2014) BEAST 2: a software platform for Bayesian evolutionary analysis. PLoS Computational Biology: 10: e1003537. https://doi.org/10.1371/journal. pcbi. 1003537

Boyer SL, Clouse RM, Benavides LR, Sharma P, Schwendinger PJ, Karunarathna I, Giribet G (2007) Biogeography of the world: a case study from cyphophthalmid Opiliones, a globally distributed group of arachnids. Journal of Biogeography 34: 2070-2085. https:// doi.org/10.1111/j.1365-2699.2007.01755.x

Boyer SL, Baker CM, Popkin-Hall ZR, Laukó DI, Wiesner HA, Quay RH (2015) Phylogeny and biogeography of the mite harvestmen (Arachnida: Opiliones: Cyphophthalmi) of 
Queensland, Australia, with a description of six new species from the rainforests of the Wet Tropics. Invertebrate Systematics 29: 37-70. https://doi.org/10.1071/IS14025

Branstetter MG, Danforth BN, Pitts JP, Faircloth BC, Ward PS, Buffington ML, Gates MW, Kula RR, Brady SG (2017) Phylogenomic insights into the evolution of stinging wasps and the origins of ants and bees. Current Biology 27: 1019-1025. https://doi.org/10.1016/j. cub.2017.03.027

Breinholt JW, Earl C, Lemmon AR, Lemmon EM, Xiao L, Kawahara AY (2017) Resolving relationships among the megadiverse butterflies and moths with a novel pipeline for Anchored Phylogenomics. Systematic Biology 67: 78-93. https://doi.org/10.1093/sysbio/syx048

Briggs TS (1969) A new holarctic family of laniatorid phalangids (Opiliones). Pan-Pacific Entomologist 45: 35 .

Briggs TS (1971a) Relict harvestmen from the Pacific northwest (Opiliones). Pan Pacific Entomologist 47: 165-178.

Briggs TS (1971b) The harvestmen of family Triaenonychidae in North America (Opiliones). Occasional Papers of the California Academy of Sciences 90: 1-43.

Briggs TS (1974) Troglobitic harvestmen recently discovered in North American lava tubes (Travuniidae, Erebomastridae, Triaenonychidae: Opiliones). Journal of Arachnology 1: 205-214. http://www.jstor.org/stable/3705196

Castresana J (2000) Selection of conserved blocks from multiple alignments for their use in phylogenetic analysis. Molecular Biology and Evolution 17: 540-552. https://doi. org/10.1093/oxfordjournals.molbev.a026334

Chemini C (1985) Descrizione del maschio di Peltonychia leprieuri (Lucas) e ridescrizione di Mitostoma orobicum (Caporiacco) (Arachnida, Opiliones). Bollettino della Societá Entomologica Italiana 117: 72-75.

Chifman J, Kubatko L (2014) Quartet inference from SNP data under the coalescent. Bioinformatics 30: 3317-3324. https://doi.org/10.1093/bioinformatics/btu530

Chifman J, Kubatko L (2015) Identifiability of the unrooted species tree topology under the coalescent model with time-reversible substitution processes, site-specific rate variation, and invariable sites. Journal of Theoretical Biology 374: 35-47. https://doi.org/10.1016/j. jtbi.2015.03.006

Derkarabetian S, Steinmann DB, Hedin M (2010) Repeated and time-correlated morphological convergence in cave-dwelling harvestmen (Opiliones, Laniatores) from montane western North America. PLoS One 5 (5): e10388. https://doi.org/10.1371/journal.pone.0010388

Derkarabetian S, Ledford J, Hedin M (2011) Genetic diversification without obvious genitalic morphological divergence in harvestmen (Opiliones, Laniatores, Sclerobunus robustus) from montane sky islands of western North America. Molecular Phylogenetics and Evolution 61: 844-853. https://doi.org/10.1016/j.ympev.2011.08.004

Derkarabetian S, Hedin M (2014) Integrative taxonomy and species delimitation in harvestmen: a revision of the western North American genus Sclerobunus (Opiliones: Laniatores: Travunioidea). PLoS One 9 (8): e104982. https://doi.org/10.1371/journal.pone.0104982

Dumitrescu DO (1974a) Contribution à l'étude de l'appareil digestif (intestin moyen) des Opilions (Arachnida). Travaux du Muséum d'Histoire naturelle (Grigore Antipa) 14: 95-107. 
Dumitrescu DO (1975) Contribution a l'étude morphologique de l'appareil digestif (intestin moyen) des opilions. Proceedings of the 6th International Arachnology Congress, Amsterdam IV, April 1974. Vrije Universiteit at Amsterdam, 150-155.

Dumitrescu DO (1976) Recherches morphologiques sur l'appareil digestif (intestin moyen) des Gonyleptomorphi (Arachnida, Opilionida). Travaux du Muséum d'Histoire naturelle (Grigore Antipa) 17: 17-30.

Faircloth BC (2013) Illumiprocessor: a Trimmomatic wrapper for parallel adapter and quality trimming. https://doi.org/10.6079/J9ILL

Faircloth BC (2015) PHYLUCE is a software package for the analysis of conserved genomic loci. Bioinformatics 32: 786-788. https://doi.org/10.1093/bioinformatics/btv646

Faircloth BC (2017) Identifying conserved genomic elements and designing universal bait sets to enrich them. Methods in Ecology and Evolution 8: 1103-1112. https://doi. org/10.1111/2041-210X.12754

Fernández R, Sharma PP, Tourinho AL, Giribet G (2017) The Opiliones tree of life: shedding light on harvestmen relationships through transcriptomics. Proceedings of the Royal Society B 284: 20162340. https://doi.org/10.1098/rspb.2016.2340

Garrison NL, Rodriguez J, Agnarsson I, Coddington JA, Griswold CE, Hamilton CA, Hedin M, Kocot KM, Ledford JM, Bond JE (2016) Spider phylogenomics: untangling the Spider Tree of Life. PeerJ 4: e1719.https://doi.org/10.7717/peerj.1719

Giribet G, Vogt L, Pérez-González A, Sharma P, Kury AB (2010) A multilocus approach to harvestman (Arachnida: Opiliones) phylogeny with emphasis on biogeography and the systematics of Laniatores. Cladistics 26: 408-437. https://doi.org/10.1111/j.10960031.2009.00296.x

Giribet G, Kury AB (2007) Phylogeny and Biogeography. In: Pinto-da-Rocha R, Machado G, Giribet G (Eds) Harvestmen: The Biology of Opiliones. Harvard University Press, Cambridge, Massachusetts, and London, England, 62-87.

Giribet G, Sharma PP, Benavides LR, Boyer SL, Clouse RM, De Bivort BL, Dimitrov D, Kawauchi GY, Murriene J, Schwendinger PJ (2011) Evolutionary and biogeographical history of an ancient and global group of arachnids (Arachnida: Opiliones: Cyphophthalmi) with a new taxonomic arrangement. Biological Journal of the Linnean Society 105: 92-130. https://doi.org/10.1111/j.1095-8312.2011.01774.x

Giribet G, Sharma PP (2015) Evolutionary biology of harvestmen (Arachnida, Opiliones). Annual Review of Entomology 60: 157-175. https://doi.org/10.1146/annurev-ento-010814-021028

Glenn TC, Nilsen R, Kieran TJ, Finger JW, Pierson TW, Bentley KE, Hoffberg S, Louha S, Garcia-De-Leon FJ, del Rio Portilla MA, Reed K, Anderson JL, Meece JK, Aggery S, Rekaya R, Alabady M, Belanger M, Winker K, Faircloth BC (2016) Adapterama I: universal stubs and primers for thousands of dual-indexed Illumina libraries (iTru \& iNext). BioRxiv 049114. https://doi.org/10.1101/049114

Gnaspini P (2007) Development. In: Pinto-da-Rocha R, Machado G, Giribet G (Eds) Harvestmen: The Biology of Opiliones. Harvard University Press, Cambridge, Massachusetts, and London, England, 455-472. 
Grabherr MG, Haas BJ, Yassour M, Levin JZ, Thompson DA, Amit I, et al. (2011) Full-length transcriptome assembly from RNA-Seq data without a reference genome. Nature Biotechnology 29: 644-652. https://doi.org/10.1038/nbt.1883

Hadži J (1932) Prilog poznavanju pećinske faune Vjetrenice. (Pseudoscorpionidea: Neobisium (Blothus) vjetrenicae sp. n., Opilionidea: Travunia vjetrenicae sp. n., Nelima troglodytes Roewer). Glas Srpske Kraljevske Akademije 151: 103-157.

Hadži J (1935) Ein eigentumlicher neuer Hölen-Opilionid aus Nord-Amerika, Cladonychium corii g.n. sp. n. Biologia Generalis 11: 49-72.

Hamilton CA, Lemmon AR, Lemmon EM, Bond JE (2016) Expanding anchored hybrid enrichment to resolve both deep and shallow relationships within the spider tree of life. BMC Evolutionary Biology 16: 212. https://doi.org/10.1186/s12862-016-0769-y

Harvey MS (2002) Short-range endemism amongst the Australian fauna: some examples from non-marine environments. Invertebrate Systematics 16: 555-570. https://doi. org/10.1071/IS02009

Hedin M, Thomas SM (2010) Molecular systematics of eastern North American Phalangodidae (Arachnida: Opiliones: Laniatores), demonstrating convergent morphological evolution in caves. Molecular Phylogenetics and Evolution 54: 107-121. https://doi.org/10.1016/j. ympev.2009.08.020

Hedin M, Starrett J, Akhter S, Schönhofer AL, Shultz JW (2012a) Phylogenomic resolution of Paleozoic divergences in harvestmen (Arachnida, Opiliones) via analysis of nextgeneration transcriptome data. PLoS One 7(8): e42888. https://doi.org/10.1371/journal. pone. 0042888

Hedin M, Tsurusaki N, Macías-Ordóñez R, Shultz JW (2012b) Molecular systematics of sclerosomatid harvestmen (Opiliones, Phalangioidea, Sclerosomatidae): geography is better than taxonomy in predicting phylogeny. Molecular Phylogenetics and Evolution 62: 224 236. https://doi.org/10.1016/j.ympev.2011.09.017

Hedin M, Derkarabetian S, Ramírez MJ, Vink C, Bond JE (2018) Phylogenomic reclassification of the world's most venomous spiders (Mygalomorphae, Atracinae), with implications for venom evolution. Scientific Reports 8: 1636. https://doi.org/10.1038/s41598-018-19946-2

Hunt GS (1990) Hickmanoxyomma, a new genus of cavernicolous harvestmen from Tasmania (Opiliones: Triaenonychidae). Records of the Australian Museum 42: 45-68. https://doi. org/10.3853/j.0067-1975.42.1990.106

Hunt GS, Hickman JL (1993) A revision of the genus Lomanella Pocock and its implications for family level classification in the Travunioidea (Arachnida: Opiliones: Triaenonychidae). Records of the Australian Museum 45: 81-119. https://doi.org/10.3853 /j.0067-1975.45.1993.131

Karaman IM (2005) Trojanella serbica gen. n., sp. n., a remarkable new troglobitic travunioid (Opiliones, Laniatores, Travunioidea). Revue Suisse de Zoologie 112: 439-456.https:// doi.org/10.5962/bhl.part.80308

Katoh K, Standley DM (2013) MAFFT multiple sequence alignment software version 7: improvements in performance and usability. Molecular Biology and Evolution 30: 772-780. https://doi.org/10.1093/molbev/mst010 
Kearse M, Moir R, Wilson A, Stones-Havas S, Cheung M, Sturrock S, Buxton S, Cooper A, Markowitz S, Duran C, Thierer T, Ashton B, Mentjies P, Drummond A (2012) Geneious Basic: an integrated and extendable desktop software platform for the organization and analysis of sequence data. Bioinformatics 28: 1647-1649. https://doi.org/10.1093/bioinformatics/bts199

Kury AB (2000, onwards) Classification of Opiliones. Museu Nacional/UFRJ website. http://www.museunacional.ufrj.br/mndi/Aracnologia/opiliones.html

Kury AB (2003a) Annotated catalogue of the Laniatores of the new World (Arachnida, Opiliones). Revista Ibérica de Aracnología 1: 5-337.

Kury AB (2003b, onwards) OmniPaper Project — The ARACNOLAB internet resource on Opilionological Taxonomic Literature. Museu Nacional/UFRJ website. Online at: http:// www.museunacional.ufrj.br/mndi/Aracnologia/pdfliteratura/pdfs opiliones.htm

Kury (2007a) Taxonomy: Travuniidae Absolon \& Kratochvíl, 1932. In: Pinto-da-Rocha R, Machado G, Giribet G (Eds) Harvestmen: The Biology of Opiliones. Harvard University Press, Cambridge, Massachusetts, and London, England, 237-239.

Kury (2007b) Taxonomy: Triaenonychidae Sørensen, 1886. In: Pinto-da-Rocha R, Machado G, Giribet G (Eds) Harvestmen: The Biology of Opiliones. Harvard University Press, Cambridge, Massachusetts, and London, England, 239-243.

Kury AB (2013) Order Opiliones Sundevall, 1833. Animal Biodiversity: An outline of higher-level classification and survey of taxonomic richness (Addenda 2013). Zootaxa 3703: 27-33. https://doi.org/10.11646/zootaxa.3703.1.7

Kury AB (2015) Opiliones are no longer the same-on suprafamilial groups in harvestmen (Arthropoda: Arachnida). Zootaxa 3925: 301-340.

Kury AB, Mendes AC (2007) Taxonomic status of the European genera of Travuniidae (Arachnida, Opiliones, Laniatores). Munis Entomology \& Zoology 2: 1-14.

Kury AB, Mendes AC, Souza DR (2014) World Checklist of Opiliones species (Arachnida). Part 1: Laniatores-Travunioidea and Triaenonychoidea. Biodiversity Data Journal 2: e4094. https://doi.org/10.3897/BDJ.2.e4094

Kury AB, Pérez-González A (2015) A companion to Part 2 of the World Checklist of Opiliones species (Arachnida): Laniatores-Samooidea, Zalmoxoidea and Grassatores incertae sedis. Biodiversity Data Journal 3: e6663. https://doi.org/10.3897/BDJ.3.e6663

Lanfear R, Calcott B, Ho SY, Guindon S (2012) PartitionFinder: combined selection of partitioning schemes and substitution models for phylogenetic analyses. Molecular Biology and Evolution 29: 1695-1701. https://doi.org/10.1093/molbev/mss020

Machado G, Pinto-da-Rocha R, Giribet G (2007) What are harvestmen? In: Pinto-da-Rocha R, Machado G, Giribet G (Eds) Harvestmen: The Biology of Opiliones. Harvard University Press, Cambridge, Massachusetts, and London, England, 1-13.

Macías-Ordóñez R, Machado G, Pérez-González A, Shultz JW (2010) Genitalic evolution in Opiliones. In: Leonard JL, Córdoba-Aguilar A (Eds) The Evolution of Primary Sexual Characters in Animals. Oxford University Press, New York, 285-306.

Martens J (1978) Spinnentiere, Arachnida: Weberknechte, Opiliones. VEB Gustav Fischer Verlag, $464 \mathrm{pp}$. 
Martens J (1986) Die Grossgliederung der Opiliones und die Evolution der Ordnung (Arachnida). In: Barrientos JA (Ed.) Actas 10 Congreso Internacional de Aracnologia, Jaca/Espana. Instituto Pirenaico de Ecologia \& Grupo de Aracnologia, Barcelona, September 1986. Juvenil, 289-310.

Maury EA (1988) Triaenonychidae sudamericanos V. Un nuevo genero de opiliones cavernicolas de la Patagonia (Opiliones, Laniatores). Mémoires de Biospéologie 15: 117-131.

Mendes AC (2009) Avaliação do status sistemático dos táxons supragenéricos de Insidiatores Loman, 1902 (Arachnida, Opiliones, Laniatores). PhD Thesis, Rio de Janeiro, Brazil: Ciências Biológicas (Zoologia) - Museu Nacional, Universidade Federal do Rio de Janeiro.

Miller MA, Pfeiffer W, Schwartz T (2010) "Creating the CIPRES Science Gateway for inference of large phylogenetic trees". Proceedings of the Gateway Computing Environments Workshop (GCE), 14 Nov. 2010, New Orleans, LA, 1-8. https://doi.org/10.1109/ GCE.2010.5676129

Mirarab S, Reaz R, Bayzid MS, Zimmermann T, Swenson MS, Warnow T (2014) ASTRAL: genome-scale coalescent-based species tree estimation. Bioinformatics 30: i541-i548. https://doi.org/10.1093/bioinformatics/btu462

Mirarab S, Warnow T (2015) ASTRAL-II: coalescent-based species tree estimation with many hundreds of taxa and thousands of genes. Bioinformatics 31: i44-i52. https://doi. org/10.1093/bioinformatics/btv234

Novak T (2004) An overview of harvestmen (Arachnida: Opiliones) in Croatia. Natura Croatica 13: 231-296. https://hrcak.srce.hr/10554

Novak T (2005) An overview of harvestmen (Arachnida: Opiliones) in Bosnia and Herzegovina. Natura Croatica 14: 301-350. https://hrcak.srce.hr/1726

Novak T, Gruber J (2000) Remarks on published data on harvestmen (Arachnida: Opiliones) from Slovenia. Annales, (Koper) Series Historia Naturalis 10: 281-308.

Özdikmen H, Demir H (2008) New family and genus names, Briggsidae nom. nov. and Briggsus nom nov., for the harvestmen (Opiliones: Laniatores). Munis Entomology and Zoology 3: 174-176.

Pérez-González A, Werneck RM (2018) A fresh look over the genital morphology of Triaenonychoides (Opiliones: Laniatores: Triaenonychidae) unravelling for the first time the functional morphology of male genitalia. Zoologischer Anzeiger 272: 81-92. https://doi. org/10.1016/j.jcz.2017.12.010

Pinto-da-Rocha R, Machado G, Giribet G (2007) Harvestmen: The Biology of Opiliones. Harvard University Press, Cambridge, Massachusetts, and London, England, 608 pp.

Pinto-da-Rocha R, Giribet G (2007) Taxonomy. In: Pinto-da-Rocha R, Machado G, Giribet G (Eds) Harvestmen: The Biology of Opiliones. Harvard University Press, Cambridge, Massachusetts, and London, England, 88-246.

Rambaut A, Drummond AJ, Suchard M (2007) Tracer v1.6. http://beast.bio.ed.ac.uk

Rambla M (1980) Neoteny in Opiliones. In: Gruber J. (Ed) Verhandlungen 8. Internationaler Arachnologen Kongress. Abgehalten an der Universität für Bodenkultur, Wien, July 1980. Egermann, 489-492.

Raspotnig G (2012) Scent gland chemistry and chemosystematics in harvestmen. Biologia Serbica 34: 5-18. 
Raspotnig G, Bodner M, Schäffer S, Koblmüller S, Schönhofer A, Karaman I (2015) Chemosystematics in the Opiliones (Arachnida): a comment on the evolutionary history of alkylphenols and benzoquinones in the scent gland secretions of Laniatores. Cladistics 31: 202-209. https://doi.org/10.1111/cla.12079

Rodriguez J, Jones TH, Sierwald P, Marek PE, Shear WA, Brewer MS, Kocot KM, Bond JE (2018) Step-wise evolution of complex chemical defenses in millipedes: a phylogenomic approach. Scientific Reports 8: 3209. https://doi.org/10.1038/s41598-018-19996-6

Roewer CF (1935) Opiliones. Fünfte Serie, zugleich eine Revision aller bisher bekannten europäischen Laniatores. Biospeologica. LXII. Archives de Zoologie Expérimentale et Générale, Paris 78: 1-96.

Roewer CF (1956) Cavernicole Arachniden aus Sardinien II. Fragmenta Entomologica, Roma 2: 97-104.

Schönhofer AL, McCormack M, Tsurusaki N, Martens J, Hedin M (2013) Molecular phylogeny of the harvestmen genus Sabacon (Arachnida: Opiliones: Dyspnoi) reveals multiple EoceneOligocene intercontinental dispersal events in the Holarctic. Molecular Phylogenetics and Evolution 66: 303-315. https://doi.org/10.1016/j.ympev.2012.10.001

Schönhofer AL, Vernesi C, Martens J, Hedin M (2015) Molecular phylogeny, biogeographic history, and evolution of cave-dwelling taxa in the European harvestman genus Ischyropsalis (Opiliones: Dyspnoi). Journal of Arachnology 43: 40-53. https://doi.org/10.1636/H1439.1

Sharma PP, Giribet G (2011) The evolutionary and biogeographic history of the armoured harvestmen-Laniatores phylogeny based on ten molecular markers, with the description of two new families of Opiliones (Arachnida). Invertebrate Systematics 25: 106-142. https:// doi.org/10.1071/IS11002

Sharma PP, Giribet G (2014) A revised dated phylogeny of the arachnid order Opiliones. Frontiers in Genetics 5: 255. https://doi.org/10.3389/fgene.2014.00255

Shear WA (1977) Fumontana deprehendor, n. gen., n. sp., the first triaenonychid opilionid from eastern North America (Opiliones: Laniatores: Triaenonychidae). Journal of Arachnology 3: $177-183$.

Shear WA (1982) Opiliones. In: Parker SP (Ed.) Synopsis and classification of living organisms, vol 2. McGraw Hill Book Co, New York, 104-110.

Shear WA (1986) A cladistic analysis of the opilionid superfamily Ischyropsalidoidea, with descriptions of the new family Ceratolasmatidae, the new genus Acuclavella, and four new species. American Museum Novitates 2844: 1-29. http://hdl.handle.net/2246/3579

Shear WA, Derkarabetian S (2008) Nomenclatorial changes in Triaenonychidae: Sclerobunus parvus Roewer is a junior synonym of Paranonychus brunneus (Banks), Mutsunonychus Suzuki is a junior synonym of Paranonychus Briggs, and Kaolinonychinae Suzuki is a junior synonym of Paranonychinae Briggs (Opiliones: Triaenonychidae). Zootaxa 1809: 67-68.

Shear WA, Jones TH, Guidry HM, Derkarabetian S, Richart CH, Minor M, Lewis JJ (2014) Chemical defenses in the opilionid infraorder Insidiatores: divergence in chemical defenses between Triaenonychidae and Travunioidea and within travunioid harvestmen (Opiliones) from eastern and western North America. Journal of Arachnology 42: 248-256. https:// doi.org/10.1636/B14-41.1 
Shultz JW, Pinto-da-Rocha R (2007). Morphology and Functional Anatomy. In: Pinto-daRocha R, Machado G, Giribet G (Eds) Harvestmen: The Biology of Opiliones. Harvard University Press, Cambridge, Massachusetts, and London, England, 14-61.

Shultz JW, Regier JC (2009) Caddo agilis and C. pepperella (Opiliones, Caddidae) diverged phylogenetically before acquiring their disjunct, sympatric distributions in Japan and North America. Journal of Arachnology 37: 238-240. https://doi.org/10.1636/H08-66.1 Sørensen WE (1886) Opiliones. In: Koch L, von Keyserling E (Eds) Die Arachniden Australiens nach der Natur beschrieben und abgebildet, Volume 2. Bauer \& Raspe, Nürnberg, 53-86.

Stamatakis A (2014) RAxML version 8: a tool for phylogenetic analysis and post-analysis of large phylogenies. Bioinformatics 30: 1312-1313. https://doi.org/10.1093/bioinformatics/btu033

Staręga W (1971) Bemerkungen uber die Verbreitung einger Familien der Weberknechte (Opiliones). In: Folk C (Ed.) Proceedings Arachnologorum Congressus Internationalis V Brno, Brno (Czechoslovakia), September, 1971. Institute of Vertebrate Zoology of the Czechoslovak Academy of Sciences, 59-63.

Starrett J, Derkarabetian S, Richart CH, Cabrero A, Hedin M (2016) A new monster from southwest Oregon forests: Cryptomaster behemoth sp. n. (Opiliones, Laniatores, Travunioidea). ZooKeys 555: 11-35. https://doi.org/10.3897/zookeys.555.6274

Starrett J, Derkarabetian S, Hedin M, Bryson RW, McCormack JE, Faircloth BC (2017) High phylogenetic utility of an ultraconserved element probe set designed for Arachnida. Molecular Ecology Resources 17: 812-823. https://doi.org/10.1111/1755-0998.12621

Suzuki S (1964) A remarkable new genus of Travuniidae (Phalangida) from Japan. Annotationes Zoologicae Japonenses 37: 168-173.

Suzuki S (1972a) Report on a collection of Opiliones from Poroshiridake, Hokkaido. Memoires of the National Science Museum Tokyo 5: 37-44.

Suzuki S (1972b) On the discontinuous distribution in some Opiliones. Acta Arachnologica 24: 1-8. https://doi.org/10.2476/asjaa.24.1

Suzuki S (1975a) The harvestmen of Family Travuniidae from Japan (Travunoidea, Opiliones, Arachnida). Journal of Science of Hiroshima University (Series B, Division 1) 26: 53-63.

Suzuki S (1975b) The harvestmen of family Triaenonychidae in Japan and Korea (Travunoidea, Opiliones, Arachnida). Journal of Science of Hiroshima University (Series B, Division 1) 26: 65-101.

Suzuki S (1976) Two triaenonychid harvestmen from the northeast, Japan (Triaenonychidae, Opiliones, Arachnida). Journal of Science of the Hiroshima University (Series B, Division 1) 26: 177-185.

Suzuki S, Tomishima K, Yano S, Tsurusaki N (1977) Discontinuous distributions in relict harvestmen (Opiliones, Arachnida). Acta Arachnologica 27: 121-138. https://doi. org/10.2476/asjaa.27.Specialnumber_121

Swofford DL (2003) PAUP*: phylogenetic analysis using parsimony, version 4.0 b10. Massachusetts: Sinauer Associates.

Talavera G, Castresana J (2007) Improvement of phylogenies after removing divergent and ambiguously aligned blocks from protein sequence alignments. Systematic Biology 56: 564-577. https://doi.org/10.1080/10635150701472164 
Tedeschi M, Sciaky R (1994) Three new Italian species of the genus Holoscotolemon (Arachnida Opiliones Erebomastridae). Bollettino del Museo Civico di Storia Naturale di Verona 18: $1-10$.

Thaler K (1996) Neue Funde europäischer Krallenweberknechte. Berichte des naturwissenschaftlichen-medizinischen Verein Innsbruck 83: 135-148.

Thomas SM, Hedin M (2008) Multigenic phylogeographic divergence in the paleoendemic southern Appalachian opilionid Fumontana deprehendor Shear (Opiliones, Laniatores, Triaenonychidae). Molecular Phylogenetics and Evolution 46: 645-658. https://doi. org/10.1016/j.ympev.2007.10.013

Thorell TTT (1876) Descrizione di alcune specie di Opilioni dell' Arcipelago Malese appartenenti al Museo Civico di Genova. Annali del Museo Civico di Storia Naturale di Genova 9: 111-138.

Ubick D, Dunlop JA (2005) On the placement of the Baltic amber harvestman Gonyleptes nemastomoides Koch \& Berendt, 1854, with notes on the phylogeny of Cladonychiidae (Opiliones, Laniatores, Travunioidea). Mitteilungen aus dem Museum für Naturkunde zu Berlin, Geowissenschaftliche Reihe 8: 75-82. https://doi.org/10.1002/mmng.200410005

Wiens JJ (2004) Speciation and ecology revisited: phylogenetic niche conservatism and the origin of species. Evolution 58: 193-197. https://doi.org/10.1111/j.0014-3820.2004. tb01586.x

Zerbino DR, Birney E (2008) Velvet: algorithms for de novo short read assembly using de Bruijn graphs. Genome Research 18: 821-829. https://doi.org/10.1101/gr.074492.107

\section{Supplementary material I}

\section{Data Table. Taxon sample and UCE sequencing results}

Authors: Shahan Derkarabetian, James Starrett, Nobuo Tsurusaki, Darrell Ubick, Stephanie Castillo Marshal Hedin

Data type: species data

Explanation note: Samples highlighted in red were sequenced for Starrett et al. (2017). Copyright notice: This dataset is made available under the Open Database License (http://opendatacommons.org/licenses/odbl/1.0/). The Open Database License $(\mathrm{ODbL})$ is a license agreement intended to allow users to freely share, modify, and use this Dataset while maintaining this same freedom for others, provided that the original source and author(s) are credited.

Link: https://doi.org/10.3897/zookeys.760.24397.suppl1 


\section{Supplementary material 2}

\section{Figures}

Authors: Shahan Derkarabetian, James Starrett, Nobuo Tsurusaki, Darrell Ubick, Stephanie Castillo Marshal Hedin

Data type: molecular data

Explanation note:

Figure 1. Outgroup relationships for the 70\% dataset. Nodes are fully supported (e.g., 100 bootstrap, 1.0 posterior probability, etc.) unless otherwise indicated. RAxML tree manually rooted according to BEAST topology. Asterisk in ASTRAL tree indicates node not given support values by default.

Figure 2. Representative midgut morphology. Only the right half of the midgut is illustrated. Drawings for Triaenonychoidea (Synthetonychia), Grassatores (Discocyrtus), Cladonychiidae, and Paranonychidae redrawn from Dumitrescu (1975, 1976). Abbreviations: D1 = diverticulum 1; OD2 = opisthosomal diverticula 2; OD3 = opisthosomal diverticula 3 .

Figure 3. Representative genital morphology and distribution of Peltonychia in Europe. Records from Slovenia and Trieste, Italy (red) are in error. Genitalia from left to right: $P$. clavigera, redrawn from Thaler (1996); P. leprieurii, redrawn from Chemini (1985); P. gabria, redrawn from Martens (1978).

Figure 4. SEM penis morphology of Yuria and Paranonychidae. Scale bars $500 \mathrm{~mm}$. Copyright notice: This dataset is made available under the Open Database License (http://opendatacommons.org/licenses/odbl/1.0/). The Open Database License $(\mathrm{ODbL})$ is a license agreement intended to allow users to freely share, modify, and use this Dataset while maintaining this same freedom for others, provided that the original source and author(s) are credited.

Link: https://doi.org/10.3897/zookeys.760.24397.suppl2 